\title{
Key Performance Indicators (KPIs) to Promote Building Developers Safety Performance in the Construction Industry
}

\author{
Abubakar Sadiq Mahmoud ${ }^{1}$ D, Mohd Hamdan Ahmad $^{1}$ (D), Yahya Mohd Yatim ${ }^{1}$ (D), Yakubu Aminu Dodo ${ }^{2}$ \\ ${ }^{1}$ Universiti Teknologi Malaysia UTM (Malaysia) \\ ${ }^{2}$ Istanbul Gelisim University (Turkey)
}

sadiqmahmoud2@gmail.com,b-hamdan@utm.mu,b-yahya@utm.my,yadodo@gelisim.edu.tr

Received: January 2020

Accepted: May 2020

\begin{abstract}
:
Purpose: The aim of this study is to establish key performance indicators (KPIs) that can be deployed in the evaluation and promotion of safety performance of building developer's in Nigeria.

Design/methodology/approach: A thorough review of the literature was performed to generally identify sets of KPIs used to evaluate the safety performances of building developer's during construction. Interviews and focus group discussions were conducted with eleven (11) subject matter experts and professionals to ensure inclusion, validation and clarity of the indicators and to further provide agreement/disagreement, and importance ratings for the identified KPIs. The KPIs was grouped into appropriate categories, keeping out redundant KPIs, and ensuring KPIs are clear and measurable. The Relative Importance Index (RII) and Mean values were computed.

Findings: Results from the study consist of 137 KPIs, grouped into 9 categories including: Planning, design and procurement, communication on \& maintenance of effective safety behaviour, construction safety policy, construction safety personnel, management effort and support, safety training and enlightenment, administration of safety processes, investigation and reporting of accidents, and rewards and sanctions for project stakeholders. These KPIs were observed to be at different levels of importance from the respondents. The following KPIs were considered based on their extreme importance judging from the respective RII values: communicating safety requirements to designer (98.18\%), safety performance set as part of contractor selection criterion (96.36\%), availability and accessibility of the relevant insurance policies $(98.18 \%)$ and appropriate issuance of motivational directives by the top management (100\%).
\end{abstract}

Originality/value: Many studies have been done in the past where KPIs as it relates to construction safety were identified. However, the specificity of these KPIs to countries other than Nigeria requires similar research be conducted to identify building developer safety performance KPIs for the Nigerian construction industry

Keywords: construction safety, key performance indicators KPIs, building developers, assessment, construction safety performance

\section{To cite this article:}

Mahmoud, A.S., Ahmad, M.H., Yatim, Y.M., \& Dodo, Y.A. (2020). Key performance indicators (KPIs) to promote building developers safety performance in the construction industry. Journal of Industrial Engineering and Management, 13(2), 371-401. https://doi.org/10.3926/jiem.3099 


\section{Introduction}

Nations all over the world consider the construction industry as a major stimulant to their economic growth and development (Okoye, Mbakwe \& Igbo 2018). According to Alarcón, Acuña, Diethelm and Pellicer (2016) the construction industry is project-based with many stakeholders consisting of professionals such as designers, building developers, contractors, subcontractors and workers among others working as a team to achieve a common goal. In achieving such goal, however, the life of workers is always threatened by occupational hazards. The complex nature of the activities carried out in building construction as noted by Muiruri \& Mulinge (2014); Suárez-Sánchez, Carvajal-Peláez and Catala-Alis (2017) lead to various impacts on the health and safety of workers with occupational risks during building production. Gambatese and Behm (2008) opine that despite the numerous ongoing research, accident still occurs.

Diugwu and Baba (2014) suggested that, successful delivery of the project depends on the level of compliance with safety regulations. This has led to the establishment of Occupational Safety and Health Administration (OSHA) to enforce safety laws and regulations (Jaselskis, Anderson \& Russel 1996). Occupational safety forms part of operations on construction site as various skills and activities are required to be done in an environment that is safe (Wachter \& Yorio, 2014). In addition, a number of research have been conducted globally in order to improve the safety performance of the construction industry (Alarcón et al., 2016; Choudhry, Fang \& Mohamed, 2007; Jannadi \& Almishari, 2003; Misiurek \& Misiurek, 2017; Okoye, Ezeokonkwo \& Ezeokoli, 2016). Many research efforts have been considered at several levels, such as design for safety", "safety culture", "safety climate", and "behaviour base safety BBS" (Choudhry, 2014; Choudhry, Fang \& Mohammed, 2007; Fang \& Wu, 2013; Toole \& Gambatese, 2008). In spite of the wide recognition of the importance of safety in the construction industry, it appears there is rare research conducted to identify building developer's safety performance indicators. Thus, it becomes pertinent to have developed some KPIs which will guide the building developer's commitment to safety performance before and throughout the construction stages. Besides, these elements will give an enabling environment for the industry.

Key Performance Indicators (KPIs) are used as a marker, or sign to assess the level of a construction safety on site, and thus, determine its specific quality and performance (Lavy, Garcia \& Dexit, 2014a,b). Also, the KPIs refers to a tool used to assess the efficiency of a facility either completed or under construction and are usually documented, which is a common construction industry approach (Preiser, Rabinowitz \& White, 1987). Lavy, Garcia and Dixit (2014a,b) amongst other researchers that identified the effectiveness of KPIs in the assessment of building performance and highlighted the significance of establishing KPIs for effective performance evaluation. However, KPIs differs in relation to the reason of assessment and typology of facility being examined and the case study at hand (Kim, Yanq, Yeo \& Kim, 2005). Previous research has sought to identify a set of causes of accidents and performance indicators to assess the safety performance of various construction stakeholders. But, there are only a few studies that have done toward building developer safety performance (Jensen, Laustsen \& Jensen, 2016). Therefore, this paper seeks to establish KPIs ideal for building developer in Nigeria. Gambatese (2000) established six 6 criteria for safety program to be successful with low injury or accident rate, the six factors can be used as a guide by building developers to ensure safety responsibilities. These factors include: (1) indicate a clear position with regard to safety; (2) ensure that safety issues are considered during project planning and design phase; (3) consider contractor previous performance on safety during the selection process, contractual agreement should address safety issues; (4) designate safety duties during the construction process; (5) take part in all project safety process during construction. Also, Construction Industry Institute - CII (2015) identified many best practices that address construction safety on the project site, these include safety planning, participation by top management, safety training and education, recognition and rewards, accident investigation and reporting. Accordingly, this study adapted 5 criteria from the work (Construction Industry Institute - CII, 2015) and 4 other criteria from the work of Gambatese 2000 as dependent variables. Thus, nine performance elements for building developers were established to ensure safety during planning, design and construction phases. The elements include: (1) the Planning, design and procurement.; (2) Communication \& maintenance of effective safety behaviour; (3) construction safety policy, (4) construction safety personnel; (5) management effort and support, (6) safety training and enlightenment, (7) administration of safety processes, (8) investigation and reporting of accidents, (9) rewards and sanctions for 
project stakeholders. Thus, the objective of this paper is to establish a set of KPIs as a causal factor for each of the 9 elements for building developer to assess their safety performance.

\section{Research Methodology}

To achieve the objective of this research, the following activities were undertaken:

- An extensive literature review was conducted to source for the broad and different KPIs appropriate to evaluate the building developers' safety performance.

- KPIs is grouped into appropriate categories, leaving out redundant KPIs, and ensuring the KPIs are unambiguous and measurable.

- Interviews and focus group discussions with eleven (11) member panel of experts and professionals were conducted to ensure inclusion, validation and clarity of the indicators and to further provide agreement/disagreement, and adequate ratings for the identified KPIs.

- Statistical analysis was performed on the results to derive the rate of agreement/disagreement with the identified KPIs, as well as the computed Relative Importance Index (RII) and the Mean Value and finally the level of importance.

- Panel member's main business includes: design, construction supervision and property development, and they all acknowledge the significance of safety on site. Details of panel members are presented in Table 1.

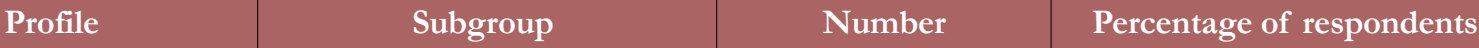

Gender

\begin{tabular}{|l|l|r|r|}
\hline & Male & 3 & $27.3 \%$ \\
\hline & Female & 8 & $72.7 \%$ \\
\hline Age & $20-30$ & 1 & $9.1 \%$ \\
\hline & $31-40$ & 4 & $36.4 \%$ \\
\hline & $41-50$ & 4 & $36.4 \%$ \\
\hline & $>51$ & 2 & $18.2 \%$ \\
\hline
\end{tabular}

Education level

\begin{tabular}{|l|l|r|r|}
\hline & $\mathrm{PhD}$ & 0 & $0.0 \%$ \\
\hline & Masters & 10 & $90.9 \%$ \\
\hline & Bachelors & 1 & $9.1 \%$ \\
\hline
\end{tabular}

Work experience in construction industry in years

\begin{tabular}{|l|l|r|r|}
\hline & $6-10$ & 4 & $36.4 \%$ \\
\hline & $11-20$ & 5 & $45.5 \%$ \\
\hline & $21-30$ & 2 & $18.2 \%$ \\
\hline
\end{tabular}

Professional certification

\begin{tabular}{|l|l|r|r|}
\hline & FNIA & 2 & $18.2 \%$ \\
\hline & MNIA & 3 & $27.3 \%$ \\
\hline & CSP & 2 & $18.2 \%$ \\
\hline & COREN & 1 & $9.1 \%$ \\
\hline & Others & 3 & $36.4 \%$ \\
\hline
\end{tabular}




\begin{tabular}{|l|l|r|r|}
\hline \multicolumn{1}{|c|}{ Profile } & \multicolumn{1}{|c|}{ Nubgroup } & Percentage of respondents \\
\hline Current engagement /designation & 1 & $9.1 \%$ \\
\hline & $\begin{array}{l}\text { Representative ministry of } \\
\text { labour }\end{array}$ & 1 & $9.1 \%$ \\
\hline & Former president NIA & 2 & $18.2 \%$ \\
\hline & $\begin{array}{l}\text { Building development control } \\
\text { (Public sector) }\end{array}$ & 2 & $18.2 \%$ \\
\hline & University lecturers & 5 & $45.5 \%$ \\
\hline & Others (private sector) & & \multicolumn{1}{|c|}{. } \\
\hline
\end{tabular}

Note: FNIA-Fellow Nigerian Institute of Architect, MNIA- Member, Nigerian Institute of Architect, CSP- Certified Safety Professional, COREN- Council for the Regulation of Engineering in Nigeria.

Table 1. Panel member's profile

\section{Key Performance Indicators for Building Developer}

Øien, Utne, Tinmannsvik and Massaiu (2011) maintain that performance indicator is considered to measure both qualitative and quantitative data, which seeks to generate information on a matter of concern with safety. They are used as indicators to assess the level of construction safety on site and it determines the quality of performance (Kim, Yanq, Yeo \& Kim, 2005). Herrera (2012) also upholds that, performance indicators play a vital part in providing information on organizational performance, increasing organizational potential for safety and motivating people to work in safety. Performance indicators, however, are not universal, and may vary according to the evaluation purpose and the case study at hand (Kim, Yanq, Yeo \& Kim, 2005). Thus, Hale (2009) state that the main function of the performance indicators is to direct the sociotechnical activity in the organization by motivating certain safety-related activities such as the practices, abilities, skills and motivation of the personnel, the organizational potential for safety. Hale also acknowledges that organizations will improve significantly if performance indicators are used for operations. However Okoro, Musonda and Agumba (2017) posit that understanding and managing organizational processes and practices is becoming a primary concern of safety management system. Herrera (2012) concludes that in order to be in controls of a site, it becomes necessary to have the required information such as safety performance indicators so as to avoid what may occur in the future like accidents. Though, many studies, like Reiman and Pietikäinen (2012), Shea, De Cieri, Donohue, Cooper and Sheehan (2016); Sinelnikov, Inouye and Kerper (2015) have been carried out to identify indicators such as "leading" and "lagging" indicators to evaluate the safety performance on site. However, lagging indicator is based on the premise of an accident occurring and taking action that is reactive. Thus, Hale (2009) argues that performance indicators are geared toward being proactive.

A number of research studies have pursued to identify the causes of construction accident and performance indicators (KPIs) for the various stakeholders in the construction industry (Chan \& Chan, 2004; Lavy et al., 2014b; Takim \& Akintoye, 2002). Thus, many studies have mentioned construction safety policy, planning, procurement and design, construction safety personnel, communication \& maintenance of effective safety behavior, management effort and support, safety training and enlightenment as important factors in ensuring safety on construction sites (Ajayi, 2016; Alzahrani \& Emsley, 2013; Dodo, 2012; Farooqui, 2011; Gambatese \& Hinze, 1999; OSHA, 2015; Teo \& Lin, 2005). In addition, administration of safety processes, accident reporting and investigation, rewards and sanctions for project stakeholders (Hinze \& Gambatese, 2003; Karakhan \& Gambatese, 2017; Umeokafor, Kostis, Lundy, Isaac, Stuart, Igwegbe et al., 2014; van der Molen, Basnet, Hoonakker, Lehtola, Lappalainen, Frings-Dresen et al., 2018) were acknowledged to influence the level of safety performance of a construction site. In summary, the $137 \mathrm{KPIs}$, grouped into 9 distinctive categories for this study were garnered from reviewing literature, design guidelines, published research papers, technical report and documents. These categories are summarized in Tables 2-9, along with their respective references. Descriptions of the 9 categories are presented in the sections that follows. 


\subsection{Construction Safety Policy}

The American Society of Civil Engineers - ASCE (2012) established that policy statement outline developer's responsibility as the pillar for improving safety performance. The policy suggested that developer's should take an active role and consider safety based on the specific project. The policy should have provision for contractor's selection based on safety records (Construction Industry Institute - CII, 2015). Xinyu and Hinze (2006) also suggest that the contractor selection should be centered on the contractor that have established safety program. In addition, Gambatese (2000) also mentioned that building developer should be proactively engaged in all phases of project management in all issues relating to safety. The study by Xinyu and Hinze (2006) concluded that a building developer can positively impact project performance by active participation at the conceptual phase. Agwu (2012) identified that total safety management, when integrated in the policy of the organizations, has the potentials of enhancing safety practices on construction sites, it is recommended that for enhanced development of individuals and organizations, improved occupational safety policy is a paramount investment in terms of precautions and safety intelligence. Inuwa, Githae \& Diang (2014) reported that comprehensive safety policy requires that safety be reflected at all project phases. It is obvious that the safety performance of workers has a strong link with safety policies of the building developer.

\subsection{Planning, Design and Procurement}

The participation of building developer at all project phases is a fundamental requirement for zero accidents on the project site (Gambatese \& Hinze, 1999; Hallowell \& Hansen, 2016). The developer is the main party in the construction industry and the beneficiary of the end product, thus, play a very significant role during the construction project life circle (Biswas, Bhattacharya \& Bhattacharya, 2017; Jazayeri, Liu \& Dadi, 2017). Usually, the building developer request the services of the designer, contractor and other industry stakeholder in the delivery of the built facility (Bello, 2012; Haslam, Hide, Gibb, Gyi, Pavitt, Atkinson et al., 2005). In line with the developer's scope of work, the designer produce the construction drawings and the contractor implement it on the site to make it a reality. Many industry practitioners perceive that safety is the responsibility of the contractors neglecting the role of other stakeholder that play a vital role in preventing the menace of accident during project execution (Heinz, Hallowell \& Baud, 2013; Toole \& Gambatese, 2008). To achieve high safety performance Huang and Hinze (2006); opined that it is essential the inclusion of safety issues at the planning stage and also providing financial support to the contractor with site monitoring. A number of researchers clarify that architect and engineers have a leading impact on the much desired safety performance on site with zero injury tolerance (Tymvios \& Gambatese, 2016). A study conducted by Gambatese, Behm and Hinze (2005) established that $42 \%$ of accident at construction site are linked to the safety design concept during the early stage. However, due to the lack of commitment from the stakeholders, designers produce working drawings without consideration to the safety during implementation. Also, according to European Foundation for the Improvement of Living and Working Conditions (Eurofound) (1991), 60\% of project accident can be mitigated if safety decision is considered at the design stage. Sadeghi, Mathieu, Tricot and Al Bassit (2015), Zhou, Whyte and Sacks (2012) opined that safety during construction project site is best determined during the early stage of planning and design conceptualization. A research conducted by Szymberski (1997) reported that construction safety is significantly impacted when safety on site is considered at the conceptual level. As shown in Figure 1 adapted from Szymberski (1997), the time/safety influence curve, demonstrate the part at which safety can be impacted for most desirable. Additionally, Anumba (1999) reported that there is an economic benefit when safety is considered at the design stage. Construction Industry Institute - CII (2003), state that considering safety at the design stage demonstrate management effort and safety commitment, and firms that implement such strategies reported fewer accidents. 


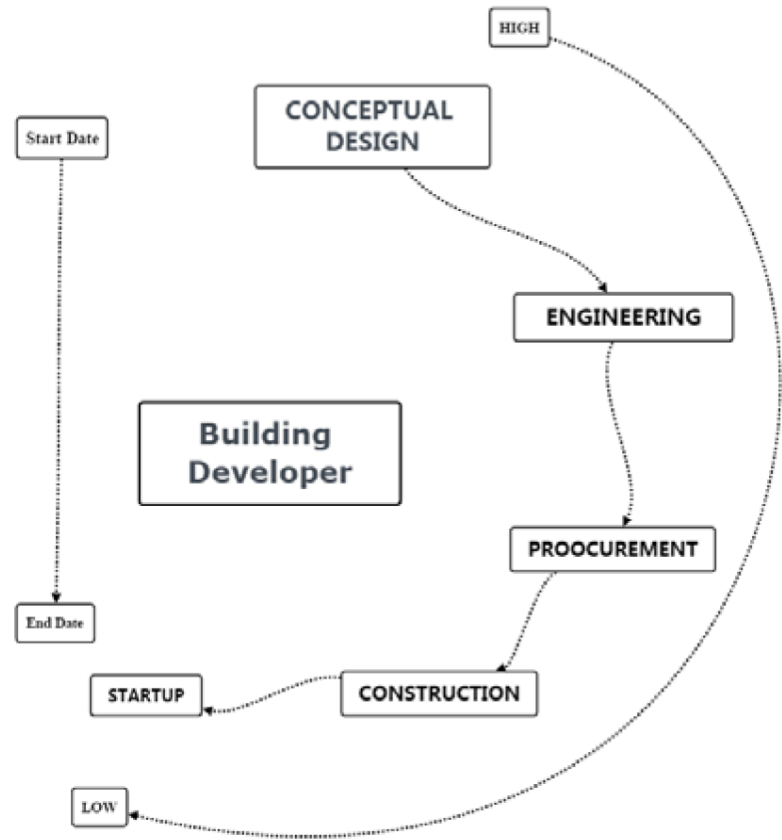

Figure 1. Time/safety influence curve (Szymberski, 1997)

\subsection{Construction Safety Personnel and Safety Culture}

Safety personnel relate to the safety and health officer who supervise the worker activities on a construction site (Gunduz, Birgonul \& Ozdemir, 2017). These activities point to the safety performance and approaches of the workers and the management in the construction industry (Biggs \& Biggs, 2013). Dingsdag, Biggs and Sheahan (2008) reported that there is a need for the engagement of safety personnel to handle the impediments to worker operations. In addition, Gunduz et al. (2017) revealed that, safety performance have proved to be positively impacted by the existence improvement in safety personnel on the project site. Zwetsloot, Kines, Ruotsala, Drupsteen, Merivirta and Bezemer (2017) recommended that safety culture covering specific factors like commitment of the management, involvement of safety personnel and adoption of safety regulations with enforcement without compromise impact significantly on the overall safety performance of a company. In a research aimed at reviewing accidents and violation of safety regulations on Nigerian construction sites, (Mahmoud, Sanni-Anibire Hassanain \& Ahmed, 2019; Aniekwu, 2007) found professionals and workers on site responsible for most accidents occurring on a site which requires a zealous effort of safety managers for the coordination of personnel and materials on site. However, this view contradicts the view of Mudi, Bioku, \& Kolawole (2015) that linked the occurrence of accidents on construction sites to indiscipline among workers, poor strategies of communication and conditions of the site.

\subsection{Communication \& Maintenance of Effective Safety Behaviour}

An efficient communication between supervisor, construction workers and the management effectively provide a better and improve compliance to safety policies and standards (Ling, Liu \& Woo, 2009). The efficiency of conveying such information is subject to the diverse ways, for example, everyday tool box meetings, posters and bulletin board (Park \& Kim, 2013). The management efforts toward safety will establish a basis for the various means of communicating the needed information to all levels of workers on the project site (CPWR, 2008). Injuries and accidents on a construction site may happen due to poor behaviour and attitudes of workers (Vinodkumar \& Bhasi, 2010). There is a direct correlation between workers' behaviour and performance of safety on construction site. Moreover, poor worker behaviour and attitudes and their negligence to safety has encourage more construction workers not to use safety gears (Idoro, 2008). In this respect, workers skills and knowledge must be translated into the commitment approach based on establishing procedures, policies or regulations and must stem out of motivation to work safely (Filstad, 2011). 


\subsection{Management Commitment and Support}

According to Zwetsloot et al. (2017) safety commitment is the extent to which organizational leadership is represented by the willingness to prevent and promote safety as part of organizational goals, values and morale. Safety performance is a concept of commitment approach based on establishing safety program. Thus far, due to increased interest toward safety commitment, several studies have been undertaken to examine how commitment can improve safety performance globally (Huang, Verma, Chang, Courtney, Lombardi, Brennan et al., 2012; Zwetsloot, et al., 2017). While the significance of safety commitment in improving safety performance is widely accepted. Many literature demonstrate how commitment served as an effective tool in improving safety performance (Abudayyeh, Fredericks, Butt \& Shaar, 2006; Barling \& Hutchinson, 2009; Michael, Evans, Jansen \& Haight, 2005; Zwetsloot et al., 2017) this has necessitated the construction industry to embrace the concept of commitment. Suraji, Duff and Peckitt (2001) shows a research conducted by the Health and Safety Executive (HSE) indicates that $75 \%$ of serious accident in the construction industry are mostly initiated by lack of management's commitment and effective support. De Silva and Walimalaratne (2012) established that the construction company with good safety performance is due to management support and commitment toward safety on the project site. Farooqui (2011) indicate that zero accident is achievable when management are committed to safety improvement and upholding to established industry standards.

\subsection{Administration of Safety Processes}

Safety administration and processes denote management of work activities on the construction site that is detrimental to the well-being of workers (Tappura, Nenonen, \& Kivistö-Rahnasto, 2017). The process of production in construction projects is evidently hampered by failure to comply with safety practice. Umoh and Torbira (2013) suggested that attitude of workers and how they behave towards the delivery of their works while minimizing accidents and increasing output is the major driver of safety practice. In his view, however, Smallwood (2002) opines that accidents cannot be avoided in the building industry and is more of a component in building production process due to the danger inherent in it; which negatively affects adherence to safety regulations. Mahmoud, Sanni-Anibire Hassanain and Ahmed (2019) found that professionals and workers on site are responsible for most accidents occurring on a site. However, this view contradicts the view of Mudi et al. (2015) that linked the occurrence of accidents on construction sites to indiscipline among workers, poor strategies of communication and conditions of the site. The main issues in managing construction site processes is the efficiency of control of many subcontractors, operating on the construction site due different specialization in trades, as such the chances of high accident occurrence will increase (Ali, Kamaruzzaman \& Sing, 2010). Moreover, sometimes contractors transfer safety responsibility to the subcontractors, thus, workers operate with unsafe practice in an unsafe environment (Shen, Ju, Koh, Rowlinson \& Bridge, 2017). Various method of construction on project site must meet different construction safety standards, policy, procedure and program. Accidents occur due to unsafe actions or unsafe conditions of work (Kadiri, Nden, Avre, Oladipo, Edom, Samuel \& Ananso, 2014). Accidents occur when unskilled workers are tasked to undertake a work they are not skilled enough to handle like loading unsafely, arranging and placing, non-use of safety/protective equipments, and exposure to hazardous materials and stressed (Wu, Li \& Fang, 2017).

\subsection{Rewards and Sanctions for Project Stakeholders}

Safety rewards are a method used in the construction industry to motivate workers to foster safety procedure and worker behaviour (Zhang, Zhou, Zhuang \& Zhu, 2015). Though, expensive and appropriate for short term (Fass, Yousef, Liginlal \& Vyas, 2017). Reward and sanction are introduce on site to signal a commitment to safety performance (Gu \& Yang, 2015). The Construction Industry Institute - CII, indicated that the most effective method is having a written safety incentive program (Construction Industry Institute - CII, 2015). Appreciation, for demonstrating a good safety procedure should be acknowledged to motivate workers (Ghasemi, Mohammadfam, Soltanian, Mahmoudi \& Zarei, 2015). However, Funso, Sammy and Gerryshom (2016) is of the view that financial reward may compromise worker's performance on safety, more so, economic reward may hinder workers to report all near misses, incident, or even accident. Thus, the study suggested a form of acknowledgement or written appreciation will boots significantly the morale of workers. Molenaar, Park and Washington (2009) identified that 
social incentive is an influential index for worker safety performance. Accordingly, workers should be actively engaged in the policy formulation and review process that will empower them to consider the risk at all levels of project execution. Though Fass et al. (2017) research findings support the system of financial reward which they argued reduced construction accident. Other researchers illustrates that despite the introduction of safety incentive, the accident situations did not change much (El-Nagar, Hosny \& Askar, 2015). Also, Alarcón et al. (2016) and Jaraiedi, Plummer and Aber (1995) debated that incentive do not significantly impact on the safety performance. Molenaar et al. (2009) indicated that incentive effectiveness depends on how they are being allocated. On the other hand, Aksorn and Hadikusumo (2008) opined that incentive and sanction on safety performance do not necessarily resulted in the anticipated output of improving safety, but rather depend on the relationship of the different stakeholders in a project. Therefore, evaluating the workers attitude and behaviour toward safety operation before engaging a contract will be able to produce a desired outcome. Building developer should identify policies, approached and strategies inculcate safety culture before and during the project implementation, though, the project completed within a time frame should be considered. (Choi \& Kwak, 2012).

\subsection{Investigation and Reporting of Accident}

Accidents happen in all kinds of construction project, the majority of accidents on construction site are as a result of unsafe environment and unsafe act (Khosravi, Asilian-Mahabadi, Hajizadeh, Hassanzadeh-Rangi, Bastani \& Behzadan, 2014; Alarcón et al., 2016). Identifying and eliminating construction accident on the project site is not always possible without identifying the causal factor through accident investigation. A number of preventive methods are acknowledged to protect workers from project site hazards or to reduce the severity of the accident. These methods involve the use of guardrail systems, safety harnessing systems, safety signs and housekeeping (Chi, Chang \& Ting, 2005). The accident investigation is aimed at the determining of all root causes of accidents and suggesting that measure should be taken to prevent future recurrence. Wu, Gibb and Li (2010) establish that company that tract incident and near misses have improved safety performance, the research also discovered that companies having a sufficient record of near misses have lower accident and injury rates. Thus, addressing the causal factor would prevent the incident from happening again, hence it will strengthen the safety performance of the company.

\subsection{Safety Training and Enlightenment}

Choudhry and Fang (2008) established that construction workers that received formal safety training and orientation record lower injury rates compared to workers that received informal orientation. OSHA (2015), indicates that part of the features of a safer firm are providing workers on the project site with training and orientation before commencing work. The International Labour Organization - ILO (1995) also promoted safety and health on construction with emphasis on training by adopting the 1988 Safety and Health in Construction Convention (No. 167), and Recommendation (No. 175). Tackett, Goodrum and Maloney (2006) shows that significant safety enhancement can be achieved by application of construction site safety training on all projects, formalized supervisor training, hiring a full-time corporate training director, computerized tracking of worker training and increased evaluation of workers' skills and knowledge upon hiring. Nevertheless, the majority of the study indicate safety orientation and training have to be considered as a prerequisite before engaging constructors on a project. Safety passport training's modules should be introduced at every construction site.

\section{Results and Findings}

\subsection{Assessment of the KPI Questionnaire Survey}

The respondents' assessments of the questionnaire survey were analysed based on the Relative Importance Index (RII) calculated according to the following equation (Dominowski, 1980; Hassanain, Sanni-Anibire, Mahmoud \& Hamida, 2019):

$$
\mathrm{RII}=\frac{\sum_{\mathrm{I}=0}^{5}\left(\mathrm{a}_{\mathrm{i}}\right)\left(\mathrm{x}_{\mathrm{i}}\right)}{5 \sum \mathrm{x}_{\mathbf{i}}} \times 100 \%
$$


Where $a_{i}$ is the constant representing the weight assigned to $i$; and $x_{i}$ is the variable representing the frequency assigned to $i$. The response for $i$ is $1,2,3,4,5$, and is illustrated as follows:

- $\quad \mathrm{x}_{0}=$ frequency of "Extremely Important" response corresponding to $\mathrm{a}_{0}=5$.

- $\quad \mathrm{x}_{1}=$ frequency of "Very Important" response corresponding to $\mathrm{a}_{1}=4$.

- $\mathrm{x}_{2}=$ frequency of "Important" response corresponding to $\mathrm{a}_{2}=3$.

- $\mathrm{x}_{3}=$ frequency of "Somewhat Important" response corresponding to $\mathrm{a}_{3}=2$.

- $\mathrm{x}_{4}=$ frequency of "Not Important" response corresponding to $\mathrm{a}_{4}=1$.

For the quantification of the level of importance for each of the KPIs, the following range was adopted:

- An RII value within $(0 \geq 12.5 \%)$ implies that, the respondents categorized the KPI as "not important".

- An RII value within $(12.5 \geq 37.5 \%)$ implies that, the respondents categorized the KPI as "somewhat important".

- An RII value within $(37.5 \geq 62.5 \%)$ implies that, the respondents categorized the KPI as "important".

- An RII value within $(62.5 \geq 87.5 \%)$ implies that, the respondents categorized the KPI as "very important".

- An RII value within $(87.5 \geq 100 \%)$ implies that, the respondents categorized the KPI as "extremely important".

Tables 1-9 is an illustration of the various KPIs in 9 categories, with their corresponding agreement levels, as well as their RII values, mean value and levels of importance. Also referred findings from similar authors that were reviewed.

\subsection{Planning, Design and Procurement}

Results in Table 2, which shares similar findings with other researchers, indicate that respondents unanimously agreed on the inclusion of 24 KPIs in the Planning, design phase and procurement. except in 7 places where about 22 respondents differed in opinion. Also, $16 \mathrm{KPIs}$ in this group (preconstruction) were ranked "extremely important" with RII values above $87.5 \%$. These include: Safety related issues considered in the feasibility study (RII of $96 \%$ ), communicating a safety requirement to the designer (RII of 98\%), and Safety performance set as part of contractor selection criterion (RII of 96\%). Contractor accident and injury rates (RII of 100\%), availability of insurance policy (RII of $100 \%$ ), safety requirements are outlined in the contract document for preselected contractors (RII of $100 \%$ ), available plan for report of injury and incidents on site by the contractor (RII of $100 \%)$ were among the KPIs ranked with RII values at 100\%. Availability of plan on accidents mitigation to be submitted by the contractor (RII of 98\%), meeting up the benchmark for "extremely important" KPIs. Although 3 KPIs were rated "important" in this category.

\begin{tabular}{|c|c|c|c|c|c|c|c|c|}
\hline \multirow[t]{2}{*}{ S/No } & \multirow[t]{2}{*}{ Performance Indicators } & \multirow[t]{2}{*}{ Agree } & \multirow[t]{2}{*}{ Disagree } & \multicolumn{3}{|c|}{ Importance Rating } & \multirow{2}{*}{$\begin{array}{c}\text { Level of } \\
\text { Importance }\end{array}$} & \multirow{2}{*}{$\begin{array}{l}\text { Ref. } \\
\text { (Similar findings } \\
\text { by other authors) }\end{array}$} \\
\hline & & & & $\begin{array}{c}\text { RII } \\
100 \%\end{array}$ & $\begin{array}{l}\text { Mean } \\
\text { value }\end{array}$ & StDev. & & \\
\hline & \multicolumn{8}{|l|}{ Design Firm Engagement } \\
\hline 1 & $\begin{array}{l}\text { Safety related issues } \\
\text { considered in the feasibility } \\
\text { study during the design } \\
\text { conceptualization phase }\end{array}$ & 11 & & 96.36 & 4.72 & 0.47 & EI & $\begin{array}{l}\text { (Bello, 2012; Luo } \\
\text { \& Van Den Brand, } \\
\text { 2016; van der } \\
\text { Molen et al., 2018) }\end{array}$ \\
\hline 2 & $\begin{array}{l}\text { Responsiveness of design } \\
\text { firms towards safety to } \\
\text { forms the bases for their } \\
\text { selection }\end{array}$ & 3 & 8 & 80.00 & 3.91 & 0.70 & $\mathrm{VI}$ & $\begin{array}{l}\text { (Umeokafor 2017; } \\
\text { Weidman, } \\
\text { Dickerson \& } \\
\text { Koebel, 2015) }\end{array}$ \\
\hline
\end{tabular}




\begin{tabular}{|c|c|c|c|c|c|c|c|c|}
\hline \multirow[t]{2}{*}{ S/No } & \multirow[t]{2}{*}{ Performance Indicators } & \multirow[t]{2}{*}{ Agree } & \multirow[t]{2}{*}{ Disagree } & \multicolumn{3}{|c|}{ Importance Rating } & \multirow{2}{*}{$\begin{array}{l}\text { Level of } \\
\text { Importance }\end{array}$} & \multirow{2}{*}{$\begin{array}{c}\text { Ref. } \\
\text { (Similar findings } \\
\text { by other authors) }\end{array}$} \\
\hline & & & & $\begin{array}{c}\text { RII } \\
100 \%\end{array}$ & $\begin{array}{l}\text { Mean } \\
\text { value }\end{array}$ & StDev. & & \\
\hline 3 & $\begin{array}{l}\text { Construction safety } \\
\text { constructability considered } \\
\text { by designers }\end{array}$ & 11 & & 94.55 & 4.64 & 0.67 & EI & $\begin{array}{l}\text { (Gambatese et al., } \\
\text { 2008) }\end{array}$ \\
\hline 4 & $\begin{array}{l}\text { Engaging safety } \\
\text { professionals to review the } \\
\text { design. }\end{array}$ & 11 & & 92.73 & 4.55 & 0.69 & EI & $\begin{array}{l}\text { (Weinstein, } \\
\text { Gambatese, Asce } \\
\text { \& Hecker, 2005) }\end{array}$ \\
\hline 5 & $\begin{array}{l}\text { Design decisions that } \\
\text { impact safety on } \\
\text { construction worker }\end{array}$ & 11 & & 81.82 & 4.45 & 0.52 & VI & $\begin{array}{l}\text { (Gambatese et al., } \\
\text { 2005) }\end{array}$ \\
\hline 6 & $\begin{array}{l}\text { Communicating safety } \\
\text { requirement to designer. }\end{array}$ & 11 & & 98.18 & 4.82 & 0.40 & EI & $\begin{array}{l}\text { (Saifullah \& Ismail, } \\
\text { 2012) }\end{array}$ \\
\hline \multirow[t]{2}{*}{7} & $\begin{array}{l}\text { Building developers safety } \\
\text { professionals are engaged } \\
\text { in reviewing the design } \\
\text { along with the designers to } \\
\text { ensure safety during the } \\
\text { construction phase. }\end{array}$ & 11 & & 92.73 & 4.64 & 0.50 & EI & $\begin{array}{l}\text { (Gambatese, Asce, } \\
\text { Toole, Asce, } \\
\text { Abowitz, Asce et } \\
\text { al., 2017) }\end{array}$ \\
\hline & \multicolumn{8}{|l|}{ Contractor Selection } \\
\hline 8 & $\begin{array}{l}\text { Safety performance sets as } \\
\text { part of contractor selection } \\
\text { criterion }\end{array}$ & 11 & & 96.36 & 4.72 & 0.47 & EI & $\begin{array}{l}\text { (Construction } \\
\text { Industry Institute - } \\
\text { CII, 2015) }\end{array}$ \\
\hline 9 & $\begin{array}{l}\text { Safety forms a criterion for } \\
\text { prequalifying contractors }\end{array}$ & 9 & 2 & 89.09 & 4.18 & 0.75 & EI & $\begin{array}{l}\text { (Construction } \\
\text { Industry Institute } \\
\text { CII, 2015) }\end{array}$ \\
\hline 10 & $\begin{array}{l}\text { Contractor accident and } \\
\text { injury rates. }\end{array}$ & 11 & & 94.55 & 4,73 & 0.46 & EI & $\begin{array}{l}\text { (Xinyu \& Hinze, } \\
2006)\end{array}$ \\
\hline 11 & $\begin{array}{l}\text { Considering safety awards } \\
\text { received by the contractor. }\end{array}$ & 8 & 3 & 56.36 & 2.82 & 1.08 & I & \multirow{4}{*}{$\begin{array}{l}\text { (Hinze 2002; } \\
\text { Dodo, 2012) }\end{array}$} \\
\hline 12 & $\begin{array}{l}\text { Safety programs applicable } \\
\text { to the services to be } \\
\text { performed }\end{array}$ & 10 & 1 & 72.73 & 3.55 & 0.52 & VI & \\
\hline 13 & $\begin{array}{l}\text { Contractor designated } \\
\text { safety supervisor }\end{array}$ & 8 & 4 & 60.00 & 3.00 & 0.45 & I & \\
\hline 14 & $\begin{array}{l}\text { Availability of contractor } \\
\text { safety } \\
\text { management/program }\end{array}$ & 9 & 2 & 60.00 & 3.00 & 0.77 & I & \\
\hline 15 & $\begin{array}{l}\text { Established accident } \\
\text { reporting and mitigating } \\
\text { program }\end{array}$ & 11 & & 96.36 & 4.82 & 0.40 & EI & $\begin{array}{l}\text { (Umeokafor, et al., } \\
\text { 2014) }\end{array}$ \\
\hline \multirow[t]{2}{*}{16} & $\begin{array}{l}\text { Availability of insurance } \\
\text { policy }\end{array}$ & 11 & & 100 & 5.00 & 0.00 & EI & (Odeyinka, 2000) \\
\hline & \multicolumn{8}{|l|}{ Contractual Arrangement } \\
\hline 17 & $\begin{array}{l}\text { Contractor to comply with } \\
\text { all applicable safety rules \& } \\
\text { regulation }\end{array}$ & 9 & 2 & 70.00 & 3.50 & 0.82 & VI & $\begin{array}{l}\text { (Ayob, Shaari, Zaki } \\
\text { \& Munaaim, 2018) }\end{array}$ \\
\hline
\end{tabular}




\begin{tabular}{|c|c|c|c|c|c|c|c|c|}
\hline \multirow[t]{2}{*}{ S/No } & \multirow[t]{2}{*}{ Performance Indicators } & \multirow[t]{2}{*}{ Agree } & \multirow[t]{2}{*}{ Disagree } & \multicolumn{3}{|c|}{ Importance Rating } & \multirow{2}{*}{$\begin{array}{l}\text { Level of } \\
\text { Importance }\end{array}$} & \multirow{2}{*}{$\begin{array}{l}\text { Ref. } \\
\text { (Similar findings } \\
\text { by other authors) }\end{array}$} \\
\hline & & & & $\begin{array}{c}\text { RII } \\
100 \%\end{array}$ & $\begin{array}{l}\text { Mean } \\
\text { value }\end{array}$ & StDev. & & \\
\hline 18 & $\begin{array}{l}\text { Safety requirements are } \\
\text { outlined in the contract } \\
\text { document for preselected } \\
\text { contractors }\end{array}$ & 11 & & 100 & 4.73 & 0.46 & EI & $\begin{array}{l}\text { (Wu, Wang, Zou \& } \\
\text { Fang, 2016) }\end{array}$ \\
\hline 19 & $\begin{array}{l}\text { Written safety program to } \\
\text { be submitted before work } \\
\text { commences }\end{array}$ & 11 & & 98.18 & 4.55 & 0.52 & EI & $\begin{array}{l}\text { (Mustapha, } \\
\text { Aigbavboa \& } \\
\text { Thwala, 2017) }\end{array}$ \\
\hline 20 & $\begin{array}{l}\text { Availability of plan on } \\
\text { accidents mitigation to be } \\
\text { submitted by the } \\
\text { contractor }\end{array}$ & 11 & & 98.18 & 4.55 & 0.69 & EI & \multirow{3}{*}{$\begin{array}{l}\text { (Asanka \& } \\
\text { Ranasinghe, 2016; } \\
\text { Hallowell \& } \\
\text { Gambatese, 2009) }\end{array}$} \\
\hline 21 & $\begin{array}{l}\text { Available plan for report of } \\
\text { injury and incidents on site } \\
\text { by the contractor }\end{array}$ & 11 & & 96.36 & 4.64 & 0.50 & EI & \\
\hline 22 & $\begin{array}{l}\text { Contractor to establish the } \\
\text { applicable site safety plan }\end{array}$ & 11 & & 83.64 & 4.18 & 0.60 & $\mathrm{VI}$ & \\
\hline 23 & $\begin{array}{l}\text { Preconstruction meeting } \\
\text { with the contractors on } \\
\text { safety matters prior to the } \\
\text { commencement of } \\
\text { construction }\end{array}$ & 11 & & 90.91 & 3.91 & 0.70 & EI & $\begin{array}{l}\text { (Hare, Cameron \& } \\
\text { Duff, 2006) }\end{array}$ \\
\hline 24 & $\begin{array}{l}\text { Involvement of the } \\
\text { building developer at all } \\
\text { project phases with regard } \\
\text { to safety. }\end{array}$ & 11 & & 93.33 & 4.64 & 0.50 & EI & (Fang \& Wu, 2013) \\
\hline
\end{tabular}

Table 2. Key Performance Indicators for Planning, design and procurement

\subsection{Communication on \& Maintenance of Effective Safety Behaviour}

As shown in Table 3 respondents unanimously agreed with the inclusion of the KPIs in this group except in two KPIs where one or two respondents differed. Meanwhile, respondents ranked all the KPIs "extremely important" except in 6 places, these include: contractor is provided with support for safety on site, defined responsibilities of site safety personnel, all project participant/stakeholders are made to understand safety plan of the project clearly, safety, commitment are communicated to contractors, health and safety implementation plan effectively communicated to all are ranked with RII of $72 \%, 85 \%, 78 \%, 81 \%, 87 \%$ and $80 \%$ respectively which were perceived by respondents to be "very important". Table 3 also shares similar findings with other researchers.

\begin{tabular}{|c|c|c|c|c|c|c|c|c|}
\hline \multirow[t]{2}{*}{ S/No } & \multirow[t]{2}{*}{ Performance Indicators } & \multirow[t]{2}{*}{ Agree } & \multirow[t]{2}{*}{ Disagree } & \multicolumn{3}{|c|}{ Importance Rating } & \multirow{2}{*}{$\begin{array}{l}\text { Level of } \\
\text { Importance }\end{array}$} & \multirow{2}{*}{$\begin{array}{l}\text { Ref. } \\
\text { (Similar findings } \\
\text { by other authors) }\end{array}$} \\
\hline & & & & $\begin{array}{l}\text { RII } \\
100 \%\end{array}$ & $\begin{array}{l}\text { Mean } \\
\text { value }\end{array}$ & StDev. & & \\
\hline & \multicolumn{8}{|c|}{ Maintenance of Effective Safety Behaviour } \\
\hline 1 & $\begin{array}{l}\text { Prioritizing safety in the } \\
\text { selection of contractors }\end{array}$ & 11 & & 98.18 & 4.91 & 0.30 & EI & $\begin{array}{l}\text { (Choe \& Leite, } \\
\text { 2017) }\end{array}$ \\
\hline 2 & $\begin{array}{l}\text { Targets accident-free } \\
\text { project completion }\end{array}$ & 11 & & 96.36 & 4.81 & 0.40 & EI & (Hinze, 2000) \\
\hline 3 & $\begin{array}{l}\text { Set appropriate procedure } \\
\text { for preventing accidents }\end{array}$ & 11 & & 92.73 & 4.73 & 0.46 & EI & $\begin{array}{l}\text { (Charehzehi \& } \\
\text { Ahankoob, 2012) }\end{array}$ \\
\hline
\end{tabular}




\begin{tabular}{|c|c|c|c|c|c|c|c|c|}
\hline \multirow[t]{2}{*}{ S/No } & \multirow[t]{2}{*}{ Performance Indicators } & \multirow[t]{2}{*}{ Agree } & \multirow[t]{2}{*}{ Disagree } & \multicolumn{3}{|c|}{ Importance Rating } & \multirow{2}{*}{$\begin{array}{l}\text { Level of } \\
\text { Importance }\end{array}$} & \multirow{2}{*}{$\begin{array}{l}\text { Ref. } \\
\text { (Similar findings } \\
\text { by other authors) }\end{array}$} \\
\hline & & & & $\begin{array}{c}\text { RII } \\
100 \%\end{array}$ & $\begin{array}{l}\text { Mean } \\
\text { value }\end{array}$ & StDev. & & \\
\hline 4 & $\begin{array}{l}\text { Promotion of safety } \\
\text { performance forms the } \\
\text { basis for the engagement } \\
\text { of construction personnel }\end{array}$ & 11 & & 100.00 & 5.00 & 0.00 & EI & (Fang \& Wu, 2013) \\
\hline 5 & $\begin{array}{l}\text { The contractor is provided } \\
\text { with support for safety on } \\
\text { site }\end{array}$ & 10 & 1 & 72.00 & 3.45 & 0.82 & VI & $\begin{array}{l}\text { (International } \\
\text { Labour } \\
\text { Organization - } \\
\text { ILO, 1995) }\end{array}$ \\
\hline 6 & $\begin{array}{l}\text { The contractor bears } \\
\text { responsibility for the safety } \\
\text { of his workers }\end{array}$ & 11 & & 100.00 & 5.00 & 0.00 & EI & $\begin{array}{l}\text { (Manu, Ankrah, } \\
\text { Proverbs \& Suresh, } \\
\text { 2013) }\end{array}$ \\
\hline 7 & $\begin{array}{l}\text { The contractor is provided } \\
\text { with a safety manual which } \\
\text { must be complied with }\end{array}$ & 11 & & 98.18 & 4.91 & 0.30 & EI & \multirow{4}{*}{ (Dodo, 2012) } \\
\hline 8 & $\begin{array}{l}\text { A minimum of one safety } \\
\text { personnel is appointed to a } \\
\text { project }\end{array}$ & 11 & & 92.73 & 4.64 & 0.67 & EI & \\
\hline 9 & $\begin{array}{l}\text { Established unit to check } \\
\text { the safety performance of } \\
\text { contractors }\end{array}$ & 11 & & 89.09 & 4.45 & 0.52 & EI & \\
\hline 10 & $\begin{array}{l}\text { Defined responsibilities of } \\
\text { site safety personnel }\end{array}$ & 11 & & 85.45 & 4.27 & 0.64 & VI & \\
\hline & \multicolumn{8}{|c|}{ Communication of Effective Safety Behaviour } \\
\hline 11 & $\begin{array}{l}\text { All project } \\
\text { participant/stakeholders } \\
\text { are made to understand the } \\
\text { safety plan of the project } \\
\text { clearly }\end{array}$ & 11 & & 78.18 & 3.91 & 0.53 & VI & \multirow{5}{*}{$\begin{array}{l}\text { (Choudhry, Fang, } \\
\text { \& Rowlinson, } \\
\text { 2008; Ulang, 2005) }\end{array}$} \\
\hline 12 & $\begin{array}{l}\text { Safety commitment is } \\
\text { communicated to } \\
\text { contractors }\end{array}$ & 9 & 2 & 81.82 & 4.09 & 0.53 & VI & \\
\hline 13 & $\begin{array}{l}\text { Communicate practically } \\
\text { anticipated hazards } \\
\text { associated with the nature } \\
\text { of the work }\end{array}$ & 11 & & 98.18 & 4.90 & 0.30 & EI & \\
\hline 14 & $\begin{array}{l}\text { Health and safety } \\
\text { implementation plan } \\
\text { effectively communicated } \\
\text { to all contractor and } \\
\text { subcontractor workers } \\
\text { within their respective } \\
\text { companies. }\end{array}$ & 11 & & 87.27 & 4.36 & 0.50 & VI & \\
\hline 15 & $\begin{array}{l}\text { Lessons learned from } \\
\text { accidents are } \\
\text { communicated to workers } \\
\text { with a view to enhancing } \\
\text { positive safety } \\
\text { performance }\end{array}$ & 11 & & 94.55 & 4.73 & 0.64 & EI & \\
\hline
\end{tabular}




\begin{tabular}{|c|c|c|c|c|c|c|c|c|}
\hline \multirow[t]{2}{*}{ S/No } & \multirow[t]{2}{*}{ Performance Indicators } & \multirow[t]{2}{*}{ Agree } & \multirow[t]{2}{*}{ Disagree } & \multicolumn{3}{|c|}{ Importance Rating } & \multirow{2}{*}{$\begin{array}{l}\text { Level of } \\
\text { Importance }\end{array}$} & \multirow{2}{*}{$\begin{array}{c}\text { Ref. } \\
\text { (Similar findings } \\
\text { by other authors) }\end{array}$} \\
\hline & & & & $\begin{array}{c}\text { RII } \\
100 \%\end{array}$ & $\begin{array}{l}\text { Mean } \\
\text { value }\end{array}$ & StDev. & & \\
\hline 16 & $\begin{array}{l}\text { Communications } \\
\text { procedures for safety are } \\
\text { established by the safety } \\
\text { program }\end{array}$ & 11 & & 80.00 & 4.00 & 0.44 & $\mathrm{VI}$ & (Ulang, 2005) \\
\hline
\end{tabular}

Table 3. Key Performance Indicators for the communication \& maintenance of effective safety behaviour

\subsection{Construction Safety Policy}

As indicated in Table 4, respondents agreed to all KPIs in this category except for 5 KPIs of which 2 KPIs has 16 respondents disagreed with the inclusion of these KPIs. Meanwhile, all the respondents ranked all the KPIs between "very important" and "extremely important" excluding 2 KPIs which were perceived as "important", including: "SMS implementation" (RII of 58\%), "Inclusion of safety basis like training on safety or experience among the criteria of recruiting workers" (RII of 51\%). This might be connected to the lack of formal safety regulation in the industry that stakeholders consider the KPIs less important. Table 4 also shows similar findings from other researchers.

\begin{tabular}{|c|c|c|c|c|c|c|c|c|}
\hline \multirow[t]{2}{*}{ S/No } & \multirow[t]{2}{*}{ Performance Indicators } & \multirow[t]{2}{*}{ Agree } & \multirow[t]{2}{*}{ Disagree } & \multicolumn{3}{|c|}{ Importance Rating } & \multirow{2}{*}{$\begin{array}{l}\text { Level of } \\
\text { Importance }\end{array}$} & \multirow{2}{*}{$\begin{array}{l}\text { Ref. } \\
\text { (Similar findings } \\
\text { by other authors) }\end{array}$} \\
\hline & & & & $\begin{array}{c}\text { RII } \\
100 \%\end{array}$ & $\begin{array}{l}\text { Mean } \\
\text { value }\end{array}$ & StDev. & & \\
\hline & \multicolumn{8}{|l|}{ Construction Safety Policy } \\
\hline 1 & $\begin{array}{l}\text { Implementation of } \\
\text { available safety rules and } \\
\text { regulations }\end{array}$ & 7 & 4 & 69.09 & 3.45 & 0.82 & VI & \multirow{3}{*}{$\begin{array}{l}\text { (Mustapha, } \\
\text { Aigbavboa \& } \\
\text { Thwala, 2017) }\end{array}$} \\
\hline 2 & $\begin{array}{l}\text { Understanding of } \\
\text { company sets down rules } \\
\text { and regulations }\end{array}$ & 11 & & 92.73 & 4.64 & 0.50 & EI & \\
\hline 3 & SMS implementation & 3 & 8 & 58.18 & 2.91 & 0.83 & I & \\
\hline 4 & $\begin{array}{l}\text { Understanding of Factories } \\
\text { Act and other applicable } \\
\text { regulations }\end{array}$ & 11 & & 81.82 & 4.09 & 0.30 & VI & (Ezenwa, 2001) \\
\hline 5 & $\begin{array}{l}\text { Understanding of permit- } \\
\text { to-work system }\end{array}$ & 11 & & 96.36 & 4.82 & 0.40 & EI & \multirow{2}{*}{ (Helix ESG, 2003) } \\
\hline 6 & $\begin{array}{l}\text { Application of the permit- } \\
\text { to-work system }\end{array}$ & 11 & & 80.00 & 4.00 & 0.44 & VI & \\
\hline 7 & $\begin{array}{l}\text { Availability and accessibility } \\
\text { of relevant insurance } \\
\text { policies }\end{array}$ & 11 & & 98.18 & 4.91 & 0.30 & EI & (Odeyinka, 2000) \\
\hline 8 & $\begin{array}{l}\text { Inclusion of } \\
\text { subcontractors in the safety } \\
\text { program }\end{array}$ & 11 & & 100 & 5.00 & 0.00 & EI & $\begin{array}{l}\text { (Diugwu \& Baba, } \\
\text { 2014) }\end{array}$ \\
\hline 9 & $\begin{array}{l}\text { Specified the roles and } \\
\text { responsibility of the } \\
\text { management team in the } \\
\text { improvement of health and } \\
\text { safety }\end{array}$ & 11 & & 96.36 & 4.82 & 0.40 & EI & $\begin{array}{l}\text { (Boyd, 2014; } \\
\text { Choudhry et al., } \\
2008 \text { ) }\end{array}$ \\
\hline
\end{tabular}




\begin{tabular}{|c|c|c|c|c|c|c|c|c|}
\hline \multirow[t]{2}{*}{ S/No } & \multirow[t]{2}{*}{ Performance Indicators } & \multirow[t]{2}{*}{ Agree } & \multirow[t]{2}{*}{ Disagree } & \multicolumn{3}{|c|}{ Importance Rating } & \multirow{2}{*}{$\begin{array}{l}\text { Level of } \\
\text { Importance }\end{array}$} & \multirow{2}{*}{$\begin{array}{l}\text { Ref. } \\
\text { (Similar findings } \\
\text { by other authors) }\end{array}$} \\
\hline & & & & $\begin{array}{c}\text { RII } \\
100 \%\end{array}$ & $\begin{array}{l}\text { Mean } \\
\text { value }\end{array}$ & StDev. & & \\
\hline 10 & $\begin{array}{l}\text { Inclusion of safety basis } \\
\text { like training on safety or } \\
\text { experience among the } \\
\text { criteria of recruiting } \\
\text { workers }\end{array}$ & 3 & 8 & 50.91 & 2.63 & 0.81 & I & \\
\hline 11 & $\begin{array}{l}\text { Documented program for } \\
\text { safety procedures }\end{array}$ & 11 & & 83.64 & 4.18 & 0.60 & VI & \\
\hline 12 & $\begin{array}{l}\text { Inclusion of safety issues } \\
\text { among the criteria for } \\
\text { engaging supervisory and } \\
\text { management personnel }\end{array}$ & 11 & & 96.36 & 4.82 & 0.40 & EI & \\
\hline 13 & $\begin{array}{l}\text { Properly planned } \\
\text { procedure for the review } \\
\text { of policy on health and } \\
\text { safety at least once } \\
\text { annually. }\end{array}$ & 11 & & 80.00 & 4.00 & 0.45 & VI & $\begin{array}{l}\text { Vitharana \& De } \\
\text { Silva, De Silva, } \\
\text { 2015) }\end{array}$ \\
\hline 14 & $\begin{array}{l}\text { The policy sets achievable } \\
\text { goals in terms of health } \\
\text { and safety performance, } \\
\text { which includes effort to } \\
\text { encourage improvement }\end{array}$ & 9 & 2 & 92.73 & 4.64 & 0.67 & EI & (Hare et al., 2006) \\
\hline 15 & $\begin{array}{l}\text { Effective procedure for the } \\
\text { implementation of safety } \\
\text { plan }\end{array}$ & 8 & 3 & 76.36 & 3.82 & 0.75 & $\mathrm{VI}$ & $\begin{array}{l}\text { (Choudhry et al., } \\
\text { 2007) }\end{array}$ \\
\hline 16 & $\begin{array}{l}\text { Documented policy on } \\
\text { personal protective } \\
\text { equipment (PPE) }\end{array}$ & 11 & & 96.36 & 4.82 & 0.40 & EI & $\begin{array}{l}\text { (Tam, Zeng \& } \\
\text { Deng, 2004) }\end{array}$ \\
\hline 17 & $\begin{array}{l}\text { Ensures that all } \\
\text { stakeholders on a project } \\
\text { comply with all legislative } \\
\text { requirements related to } \\
\text { health and safety }\end{array}$ & 11 & & 76.36 & 3.82 & 0.40 & $\mathrm{VI}$ & $\begin{array}{l}\text { (Hare \& Cameron, } \\
\text { 2012) }\end{array}$ \\
\hline 18 & $\begin{array}{l}\text { Establishing relevant } \\
\text { policies, standards and safe } \\
\text { work practices necessary to } \\
\text { address worker safety }\end{array}$ & 11 & & 100 & 5.00 & 0.00 & EI & $\begin{array}{l}\text { (Hare \& Cameron, } \\
\text { 2012) }\end{array}$ \\
\hline
\end{tabular}

Table 4. Key Performance Indicators for construction safety policy

\subsection{Construction Safety Workers}

Two or three respondents in this category disagreed with 3 out of the 9 KPIs as shown in Table 5. However, all the KPIs in this category was ranked between "very important" and "extremely important" with factors such as "demonstration of safety culture by the management", "availability of health and safety training", "language and communication challenges by workers are adequately resolved before work started" having an RII value of $100 \%$. Also, similar findings by other authors is shown in Table 5. 


\begin{tabular}{|c|c|c|c|c|c|c|c|c|}
\hline \multirow[t]{2}{*}{ S/No } & \multirow[t]{2}{*}{ Performance Indicators } & \multirow[t]{2}{*}{ Agree } & \multirow[t]{2}{*}{ Disagree } & \multicolumn{3}{|c|}{ Importance Rating } & \multirow{2}{*}{$\begin{array}{l}\text { Level of } \\
\text { Importance }\end{array}$} & \multirow{2}{*}{$\begin{array}{l}\text { Ref. } \\
\text { (Similar findings } \\
\text { by other authors) }\end{array}$} \\
\hline & & & & $\begin{array}{l}\text { RII } \\
100 \%\end{array}$ & $\begin{array}{l}\text { Mean } \\
\text { value }\end{array}$ & StDev. & & \\
\hline & \multicolumn{8}{|c|}{ Construction Workers Safety } \\
\hline 1 & $\begin{array}{l}\text { Implementation of safe } \\
\text { working attitude and } \\
\text { behaviour of workers and } \\
\text { supervisors }\end{array}$ & 8 & 3 & 76.36 & 3.82 & 0.40 & VI & (Teo \& Lin, 2005) \\
\hline 2 & $\begin{array}{l}\text { Demonstration of safety } \\
\text { culture by the management }\end{array}$ & 11 & & 100 & 5.00 & 0.00 & EI & $\begin{array}{l}\text { (Agwu \& Olele, } \\
\text { 2014) }\end{array}$ \\
\hline 3 & $\begin{array}{l}\text { Availability of health and } \\
\text { safety training }\end{array}$ & 11 & & 100 & 5.00 & 0.00 & EI & $\begin{array}{l}\text { (van der Molen et } \\
\text { al., 2018) }\end{array}$ \\
\hline 4 & $\begin{array}{l}\text { Define the roles and } \\
\text { responsibilities of safety } \\
\text { committees }\end{array}$ & 9 & 2 & 67.27 & 3.36 & 0.80 & VI & $\begin{array}{l}\text { (Williams, 2008; } \\
\text { Williams, } \\
\text { Adul-Hamid \& } \\
\text { Misnan, 2018) }\end{array}$ \\
\hline 5 & $\begin{array}{l}\text { Workers understand the } \\
\text { goals and objectives of the } \\
\text { safety committee }\end{array}$ & 8 & 3 & 63.64 & 3.36 & 0.92 & VI & (Teo \& Lin, 2005) \\
\hline 6 & $\begin{array}{l}\text { Language and } \\
\text { communication challenges } \\
\text { by workers are adequately } \\
\text { resolved before work } \\
\text { started }\end{array}$ & 11 & & 100 & 5.00 & 0.00 & EI & $\begin{array}{l}\text { (Cheng \& Wu, } \\
\text { 2013) }\end{array}$ \\
\hline 7 & $\begin{array}{l}\text { Adaptation of the working } \\
\text { environment by workers }\end{array}$ & 11 & & 72.73 & 3.64 & 0.50 & VI & (Teo \& Lin, 2005) \\
\hline 8 & $\begin{array}{l}\text { Cultural background of the } \\
\text { workers are considered }\end{array}$ & 11 & & 68.00 & 3.27 & 0.90 & VI & \\
\hline 9 & $\begin{array}{l}\text { Consideration of } \\
\text { educational level of } \\
\text { workers }\end{array}$ & 11 & & 94.55 & 5.00 & 0.00 & EI & $\begin{array}{l}\text { (Chuks \& } \\
\text { Uchenna, 2012) }\end{array}$ \\
\hline
\end{tabular}

Table 5. Key Performance Indicators for Construction Safety Workers

\subsection{Management Effort and Support}

Results presented in Table 6 indicate that respondents were in complete agreement with all the 17 KPIs except in two or three respondents differed in opinion on 9 KPIs. It is also acknowledged that 29 respondents disagreed with the inclusion of 5 out of the 9 KPIs. These are: provision for review of injury reports by top management (RII of $58 \%$ ), direct involvement of top management in the activities of safety committees (RII of 56\%), accident cases reported on a site influence the number of safety personnel deployed to the site (RII of 51\%). Top management directly takes part in the enforcement of safety on sites (RII of 36\%), and corporate safety targets are set by the management (RII of 56\%). Moreover, all other KPIs are ranked between "very important" and extremely important' with RII values above 63\%. Table 6 also shows similar findings by other authors. 


\begin{tabular}{|c|c|c|c|c|c|c|c|c|}
\hline \multirow[t]{2}{*}{ S/No } & \multirow[t]{2}{*}{ Performance Indicators } & \multirow[t]{2}{*}{ Agree } & \multirow[t]{2}{*}{ Disagree } & \multicolumn{3}{|c|}{ Importance Rating } & \multirow{2}{*}{$\begin{array}{l}\text { Level of } \\
\text { Importance }\end{array}$} & \multirow{2}{*}{$\begin{array}{l}\text { Ref. } \\
\text { (Similar findings } \\
\text { by other authors) }\end{array}$} \\
\hline & & & & $\begin{array}{c}\text { RII } \\
100 \%\end{array}$ & $\begin{array}{l}\text { Mean } \\
\text { value }\end{array}$ & StDev & & \\
\hline & \multicolumn{8}{|c|}{ Management Effort and Support } \\
\hline 1 & $\begin{array}{l}\text { Management emphasis on } \\
\text { the establishment of safety } \\
\text { committees for all projects }\end{array}$ & 8 & 3 & 63.64 & 3.18 & 0.406 & VI & $\begin{array}{l}\text { (Choudhry \& } \\
\text { Fang, 2008) }\end{array}$ \\
\hline 2 & $\begin{array}{l}\text { Monitoring of contractor's } \\
\text { performance in terms of } \\
\text { safety on the construction } \\
\text { projects }\end{array}$ & 11 & & 98.18 & 4.90 & 0.302 & EI & (Idoro, 2012) \\
\hline 3 & $\begin{array}{l}\text { Safety makes a major } \\
\text { criterion for evaluating the } \\
\text { performance of a } \\
\text { supervisor }\end{array}$ & 9 & 2 & 76.36 & 3.81 & 0.603 & VI & $\begin{array}{l}\text { (Choudhry \& } \\
\text { Fang, 2008) }\end{array}$ \\
\hline 4 & \begin{tabular}{|l} 
Availability of proper \\
procedure for receiving and \\
reviewing feedback of \\
workers on health and \\
safety related issues
\end{tabular} & 10 & 1 & 76.36 & 3.81 & 0.404 & VI & $\begin{array}{l}\text { (Hinze, Asce, } \\
\text { Hallowell, Asce \& } \\
\text { Baud, 2013) }\end{array}$ \\
\hline 5 & $\begin{array}{l}\text { Provision for review of } \\
\text { injury reports by top } \\
\text { management }\end{array}$ & 5 & 6 & 58.18 & 2.90 & 0.700 & I & $\begin{array}{l}\text { (Haslam et al., } \\
\text { 2005) }\end{array}$ \\
\hline 6 & $\begin{array}{l}\text { Appropriate issuance of } \\
\text { motivational directives by } \\
\text { the top management to } \\
\text { enhance safety }\end{array}$ & 11 & & 100 & 5.00 & 0.00 & EI & $\begin{array}{l}\text { (Delegach, Kark, } \\
\text { Katz-Navon \& van } \\
\text { Dijk, 2017) }\end{array}$ \\
\hline 7 & $\begin{array}{l}\text { Involvement of top } \\
\text { management in the } \\
\text { establishment of reward } \\
\text { system to enhance adherence } \\
\text { to safety plan by all personnel }\end{array}$ & 9 & 2 & 83.64 & 4.18 & 0.751 & VI & $\begin{array}{l}\text { (Hu, Chan, Le, } \\
\text { Jiang, Xie \& Hon, } \\
\text { 2012) }\end{array}$ \\
\hline 8 & $\begin{array}{l}\text { Direct involvement of top } \\
\text { management in the activities } \\
\text { of safety committees }\end{array}$ & 2 & 9 & 56.36 & 2.63 & 0.809 & I & $\begin{array}{l}\text { (Choudhry \& } \\
\text { Fang, 2008) }\end{array}$ \\
\hline 9 & $\begin{array}{l}\text { Obvious emphasis on the } \\
\text { management on safe work } \\
\text { above output }\end{array}$ & 10 & 1 & 72.73 & 3.81 & 0.603 & VI & $\begin{array}{l}\text { (Alarcón et al., } \\
\text { 2016) }\end{array}$ \\
\hline 10 & $\begin{array}{l}\text { Accident cases reported on } \\
\text { a site influence the number } \\
\text { of safety personnel } \\
\text { deployed to the site }\end{array}$ & 8 & 3 & 50.91 & 2.54 & 0.934 & I & $\begin{array}{l}\text { (Fonseca, Lima \& } \\
\text { Duarte, 2014) }\end{array}$ \\
\hline 11 & $\begin{array}{l}\text { Top management directly } \\
\text { takes part in the enforcement } \\
\text { of safety on sites. }\end{array}$ & 3 & 8 & 36.36 & 2.09 & 1.04 & SI & \\
\hline 12 & $\begin{array}{l}\text { Corporate safety targets are } \\
\text { set by the management }\end{array}$ & 8 & 3 & 56.36 & 2.81 & 0.404 & I & $\begin{array}{l}\text { (Alarcón et al., } \\
\text { 2016) }\end{array}$ \\
\hline 13 & $\begin{array}{l}\text { Availability of personnel } \\
\text { specifically responsible for } \\
\text { handling and implementation } \\
\text { of safety policy }\end{array}$ & 11 & & 78.18 & 3.90 & 0.539 & VI & \\
\hline
\end{tabular}




\begin{tabular}{|c|c|c|c|c|c|c|c|c|}
\hline \multirow[t]{2}{*}{ S/No } & \multirow[t]{2}{*}{ Performance Indicators } & \multirow[t]{2}{*}{ Agree } & \multirow[t]{2}{*}{ Disagree } & \multicolumn{3}{|c|}{ Importance Rating } & \multirow{2}{*}{$\begin{array}{l}\text { Level of } \\
\text { Importance }\end{array}$} & \multirow{2}{*}{$\begin{array}{c}\text { Ref. } \\
\text { (Similar findings } \\
\text { by other authors) }\end{array}$} \\
\hline & & & & $\begin{array}{c}\text { RII } \\
100 \%\end{array}$ & $\begin{array}{l}\text { Mean } \\
\text { value }\end{array}$ & StDev & & \\
\hline 14 & $\begin{array}{l}\text { Emphasis on open } \\
\text { discussion between } \\
\text { workers and supervisors on } \\
\text { safety related matters }\end{array}$ & 11 & & 83.64 & 4.81 & 0.404 & VI & $\begin{array}{l}\text { (Choudhry \& } \\
\text { Fang, 2008) }\end{array}$ \\
\hline 15 & $\begin{array}{l}\text { Encourages involvement } \\
\text { of workers on decisions } \\
\text { that affect safety on site }\end{array}$ & 11 & & 98.18 & 4.90 & 0.301 & EI & \multirow{3}{*}{$\begin{array}{l}\text { (Park \& Kim, } \\
\text { 2013; Choudhry \& } \\
\text { Fang, 2008) }\end{array}$} \\
\hline 16 & $\begin{array}{l}\text { Involvement of workers in } \\
\text { preparation of safety } \\
\text { programs for the site }\end{array}$ & 11 & & 100 & 5.00 & 0.00 & EI & \\
\hline 17 & $\begin{array}{l}\text { Subcontractors are } \\
\text { involved in all aspects of } \\
\text { site safety issues }\end{array}$ & 11 & & 94.55 & 4.72 & 0.467 & EI & \\
\hline
\end{tabular}

Table 6. Key Performance Indicators for Management Effort and Support

\subsection{Safety Training and Orientation}

Respondents unanimously agreed with the inclusion of the KPIs in this group except in six KPIs where one or two respondents differed or disagreed. Perceived levels of importance are "very important", as shown in Table 7 that shares similar findings with other researchers. 5 KPIs is rated as "extremely important" with RII values between 96\%-100\%, indicating appreciation for inclusion of the KPIs. However, the KPI that is rated the lowest in this category is "a training meeting for all supervisors is required by the safety program" with RII of $70.91 \%$ which shows disagreement with the KPIs.

\begin{tabular}{|c|c|c|c|c|c|c|c|c|}
\hline \multirow[t]{2}{*}{ S/No } & \multirow[t]{2}{*}{ Performance Indicators } & \multirow[t]{2}{*}{ Agree } & \multirow[t]{2}{*}{ Disagree } & \multicolumn{3}{|c|}{ Importance Rating } & \multirow{2}{*}{$\begin{array}{l}\text { Level of } \\
\text { Importance }\end{array}$} & \multirow{2}{*}{$\begin{array}{c}\text { Ref. } \\
\text { (Similar findings } \\
\text { by other authors) }\end{array}$} \\
\hline & & & & $\begin{array}{c}\text { RII } \\
100 \%\end{array}$ & $\begin{array}{l}\text { Mean } \\
\text { value }\end{array}$ & StDev. & & \\
\hline & \multicolumn{8}{|c|}{ Safety Training and Orientation } \\
\hline 1 & $\begin{array}{l}\text { Workers to undergo } \\
\text { orientation on safety } \\
\text { before work commences } \\
\text { on site }\end{array}$ & 11 & & 98.18 & 5.00 & 0.00 & EI & $\begin{array}{l}\text { (Choudhry \& } \\
\text { Fang, 2008) }\end{array}$ \\
\hline 2 & $\begin{array}{l}\text { Supervisors are trained and } \\
\text { oriented to health and } \\
\text { safety }\end{array}$ & 9 & 2 & 76.36 & 3.27 & 0.78 & VI & $\begin{array}{l}\text { (Sacks, Perlman \& } \\
\text { Barak, 2013) }\end{array}$ \\
\hline 3 & $\begin{array}{l}\text { Safety program covers the } \\
\text { training of workers on the } \\
\text { field }\end{array}$ & 10 & 1 & 74.55 & 3.73 & 0.46 & VI & \multirow{3}{*}{$\begin{array}{l}\text { (Tackett et al., } \\
\text { 2006) }\end{array}$} \\
\hline 4 & $\begin{array}{l}\text { Provision is made in the } \\
\text { budget for safety } \\
\text { training/education }\end{array}$ & 11 & & 98.18 & 4.91 & 0.30 & EI & \\
\hline 5 & $\begin{array}{l}\text { The management staff is } \\
\text { trained on health and safety }\end{array}$ & 11 & & 96.36 & 4.82 & 0.40 & EI & \\
\hline 6 & $\begin{array}{l}\text { Discussion of safety on } \\
\text { site activities and possible } \\
\text { incidents is required by the } \\
\text { safety program }\end{array}$ & 11 & & 98.18 & 4.91 & 0.30 & EI & (Elliott, 2016) \\
\hline
\end{tabular}




\begin{tabular}{|c|c|c|c|c|c|c|c|c|}
\hline \multirow[t]{2}{*}{ S/No } & \multirow[t]{2}{*}{ Performance Indicators } & \multirow[t]{2}{*}{ Agree } & \multirow[t]{2}{*}{ Disagree } & \multicolumn{3}{|c|}{ Importance Rating } & \multirow{2}{*}{$\begin{array}{l}\text { Level of } \\
\text { Importance }\end{array}$} & \multirow{2}{*}{$\begin{array}{l}\text { Ref. } \\
\text { (Similar findings } \\
\text { by other authors) }\end{array}$} \\
\hline & & & & $\begin{array}{l}\text { RII } \\
100 \%\end{array}$ & $\begin{array}{l}\text { Mean } \\
\text { value }\end{array}$ & StDev. & & \\
\hline 7 & $\begin{array}{l}\text { Conduct safety orientation } \\
\text { for all site visitors is } \\
\text { required by the safety } \\
\text { program }\end{array}$ & 9 & 2 & 78.18 & 3.00 & 0.63 & VI & \multirow{6}{*}{$\begin{array}{l}\text { (Sacks et al., 2013; } \\
\text { OSHA, 2015) }\end{array}$} \\
\hline 8 & $\begin{array}{l}\text { New skills are checked to } \\
\text { monitor impact of training } \\
\text { on health and safety }\end{array}$ & 10 & 1 & 83.64 & 4.18 & 0.05 & $\mathrm{VI}$ & \\
\hline 9 & $\begin{array}{l}\text { The safety plan arranges } \\
\text { for formal orientation of } \\
\text { subcontractors }\end{array}$ & 11 & & 83.64 & 5.00 & 0.00 & VI & \\
\hline 10 & $\begin{array}{l}\text { Define level of safety and } \\
\text { awareness required of all } \\
\text { workers }\end{array}$ & 10 & 1 & 75.00 & 4.18 & 0.40 & VI & \\
\hline 11 & $\begin{array}{l}\text { Safety program requires a } \\
\text { safety orientation plan for } \\
\text { all new individuals to the } \\
\text { site }\end{array}$ & 9 & 2 & 72.00 & 3.60 & 0.80 & VI & \\
\hline 12 & $\begin{array}{l}\text { A training meeting for all } \\
\text { supervisors is required by } \\
\text { the safety program }\end{array}$ & 11 & & 70.91 & 3.54 & 0.52 & VI & \\
\hline 13 & $\begin{array}{l}\text { A well-written policy for } \\
\text { health and safety training in } \\
\text { the safety program }\end{array}$ & 11 & & 100.00 & 5.00 & 0.00 & EI & \multirow{4}{*}{$\begin{array}{l}\text { (Sacks et al., 2013; } \\
\text { OSHA, 2015) }\end{array}$} \\
\hline 14 & $\begin{array}{l}\text { Safety program inspires } \\
\text { active participation of } \\
\text { workers in training sessions }\end{array}$ & 11 & & 78.18 & 4.90 & 0.30 & VI & \\
\hline 15 & $\begin{array}{l}\text { Safety program requires } \\
\text { training certifications for } \\
\text { operation of equipment. }\end{array}$ & 11 & & 74.55 & 3.81 & 0.40 & $\mathrm{VI}$ & \\
\hline 16 & $\begin{array}{l}\text { Training is provided to } \\
\text { workers at a minimum for } \\
\text { new site work }\end{array}$ & 11 & & 78.18 & 3.91 & 0.53 & VI & \\
\hline
\end{tabular}

Table 7. Key Performance Indicators for Safety Training and Orientation

\subsection{Administration of Safety and Processes}

A total of 18 KPIs has been represented in this category as shown in Table 8. All respondents unanimously agreed on the inclusion of the KPIs except 2 with 11 respondents disagreed. Furthermore, about 16 KPIs are perceived as "very important" while $1 \mathrm{KPI}$ is perceived as "extremely important" which represent the highest level of importance in this category "workers' commitment to safe work practice are rewarded" with an RII value of $100 \%$. The KPI with the lowest perceived rating is "safety program requires emergency response drills" which has an RII value of $45.45 \%$, which indicate a lack of significant value for response drills in eliminating accident on the site, also 9 respondents disagreed with this KPI. Similarly, other researchers share similar findings as shown in Table 8. 


\begin{tabular}{|c|c|c|c|c|c|c|c|c|}
\hline \multirow[t]{2}{*}{ S/No } & \multirow[t]{2}{*}{ Performance Indicators } & \multirow[t]{2}{*}{ Agree } & \multirow[t]{2}{*}{ Disagree } & \multicolumn{3}{|c|}{ Importance Rating } & \multirow{2}{*}{$\begin{array}{c}\text { Level of } \\
\text { Importance }\end{array}$} & \multirow{2}{*}{$\begin{array}{l}\text { Ref. } \\
\text { (Similar findings } \\
\text { by other authors) }\end{array}$} \\
\hline & & & & $\begin{array}{l}\text { RII } \\
100 \%\end{array}$ & $\begin{array}{l}\text { Mean } \\
\text { value }\end{array}$ & StDev. & & \\
\hline & \multicolumn{8}{|c|}{ Administration of Safety and Processes } \\
\hline 1 & $\begin{array}{l}\text { Established procedure to } \\
\text { measure safety achievements }\end{array}$ & 11 & & 76.36 & 4.90 & 0.30 & VI & $\begin{array}{l}\text { (Arezes \& } \\
\text { Sérgio-Miguel, 2003) }\end{array}$ \\
\hline 2 & $\begin{array}{l}\text { Investigate non-compliance } \\
\text { for proper use of personal } \\
\text { protective equipment (PPE) }\end{array}$ & 11 & & 82.27 & 4.36 & 0.67 & VI & (Chi, et al., 2005) \\
\hline 3 & $\begin{array}{l}\text { Workers commitment to } \\
\text { safe work practice are } \\
\text { rewarded }\end{array}$ & 11 & & 100 & 5.00 & 0.00 & EI & $\begin{array}{l}\text { (Zahoor, Chan, } \\
\text { Utama, Gao \& } \\
\text { Zafar, 2017) }\end{array}$ \\
\hline 4 & $\begin{array}{l}\text { Rules of work are routinely } \\
\text { reviewed }\end{array}$ & 11 & & 81.82 & 4.09 & 0.53 & VI & $\begin{array}{l}\text { (Hale \& Borys, } \\
\text { 2013) }\end{array}$ \\
\hline 5 & $\begin{array}{l}\text { Provision for the } \\
\text { monitoring of safety } \\
\text { inspection to understand } \\
\text { its impact and coverage }\end{array}$ & 11 & & 83.64 & 4.18 & 0.60 & VI & \multirow{3}{*}{ (Saurin, 2016) } \\
\hline 6 & $\begin{array}{l}\text { Proper planning towards } \\
\text { retrieval and analysis of } \\
\text { safety inspection reports }\end{array}$ & 11 & & 81.82 & 4.00 & 0.89 & VI & \\
\hline 7 & $\begin{array}{l}\text { Proper planning to ensure } \\
\text { actions are taken based on } \\
\text { the analysed reports of } \\
\text { inspection }\end{array}$ & 9 & 2 & 74.55 & 3.72 & 0.78 & VI & \\
\hline 8 & $\begin{array}{l}\text { Safety site layout is made } \\
\text { before the commencement } \\
\text { of the project }\end{array}$ & 11 & & 78.18 & 3,81 & 0.60 & VI & \multirow{2}{*}{$\begin{array}{l}\text { (Huang \& Wong, } \\
\text { 2015) }\end{array}$} \\
\hline 9 & $\begin{array}{l}\text { Safety issues are discussed } \\
\text { at preconstruction and } \\
\text { progress meetings }\end{array}$ & 11 & & 85.45 & 4.27 & 0.46 & VI & \\
\hline 10 & $\begin{array}{l}\text { Procedures for identifying } \\
\text { safety risk and its } \\
\text { management are } \\
\text { established in the safety } \\
\text { program }\end{array}$ & 11 & & 80.00 & 4.00 & 0.63 & VI & $\begin{array}{l}\text { (Arezes \& } \\
\text { Sérgio-Miguel, } \\
\text { 2003) }\end{array}$ \\
\hline 11 & $\begin{array}{l}\text { Safety program requires } \\
\text { emergency response drills }\end{array}$ & 2 & 9 & 45.45 & 2.27 & 0.90 & I & \multirow[b]{2}{*}{$\begin{array}{l}\text { (Hallowell \& } \\
\text { Gambatese, 2009) }\end{array}$} \\
\hline 12 & $\begin{array}{l}\text { Provision is made for } \\
\text { safety bulletin boards } \\
\text { accessible to workers } \\
\text { during working hours }\end{array}$ & 11 & & 78.18 & 3.91 & 0.30 & VI & \\
\hline 13 & $\begin{array}{l}\text { Maintenance of a site } \\
\text { accident record book to } \\
\text { document accidents, } \\
\text { impact and preventive } \\
\text { safety measures. }\end{array}$ & 11 & & 94.55 & 5.00 & 0.00 & VI & \multirow[t]{2}{*}{$\begin{array}{l}\text { (Hallowell \& } \\
\text { Gambatese, 2009) }\end{array}$} \\
\hline 14 & $\begin{array}{l}\text { Posters and signs for site } \\
\text { safety are obviously } \\
\text { displayed on the project } \\
\text { site }\end{array}$ & 11 & & 80.00 & 4.00 & 0.44 & VI & \\
\hline
\end{tabular}




\begin{tabular}{|c|c|c|c|c|c|c|c|c|}
\hline \multirow[t]{2}{*}{ S/No } & \multirow[t]{2}{*}{ Performance Indicators } & \multirow[t]{2}{*}{ Agree } & \multirow[t]{2}{*}{ Disagree } & \multicolumn{3}{|c|}{ Importance Rating } & \multirow{2}{*}{$\begin{array}{c}\text { Level of } \\
\text { Importance }\end{array}$} & \multirow{2}{*}{$\begin{array}{l}\text { Ref. } \\
\text { (Similar findings } \\
\text { by other authors) }\end{array}$} \\
\hline & & & & $\begin{array}{c}\text { RII } \\
100 \%\end{array}$ & $\begin{array}{l}\text { Mean } \\
\text { value }\end{array}$ & StDev. & & \\
\hline 15 & $\begin{array}{l}\text { Safe operational } \\
\text { procedures for all } \\
\text { contractors and } \\
\text { subcontractor are } \\
\text { documented. }\end{array}$ & 11 & & 81.82 & 4.09 & 0.30 & VI & \\
\hline 16 & $\begin{array}{l}\text { Procedures for checking } \\
\text { the appropriate utilization } \\
\text { of PPE as well as } \\
\text { inspection and training are } \\
\text { established. }\end{array}$ & 11 & & 83.64 & 4.18 & 0.40 & VI & \multirow[t]{2}{*}{$\begin{array}{l}\text { (Haslam et al., } \\
\text { 2005) }\end{array}$} \\
\hline 17 & $\begin{array}{l}\text { Available/appropriate } \\
\text { PPEs on project sites. }\end{array}$ & 11 & & 83.64 & 4.18 & 0.40 & VI & \\
\hline 18 & $\begin{array}{l}\text { Adequate provision of } \\
\text { First Aid and CPR facilities } \\
\text { on project sites }\end{array}$ & 11 & & 80.00 & 4.00 & 0.63 & $\mathrm{VI}$ & $\begin{array}{l}\text { (Findley, Smith, } \\
\text { Kress, Petty \& } \\
\text { Enoch, 2004) }\end{array}$ \\
\hline
\end{tabular}

Table 8. Key Performance Indicators for Administration of Safety and Processes

\subsection{Investigation and Reporting of Accident}

All participants unanimously agreed the inclusions to all KPIs in this group and the perceived level of importance to be "very important", as shown in Table 9, except one KPI "near misses are reported in the incident logs" which is perceived to be "extremely important". The KPI with the lowest RII was "utilization of safety reports for the improvement of safety performance" (RII of 69.09\%) which shows respondents perceived level of importance in reducing accidents on sites. Also, Table 9 shows similar research outcome by other authors.

\begin{tabular}{|c|c|c|c|c|c|c|c|c|}
\hline \multirow[t]{2}{*}{ S/No } & \multirow[t]{2}{*}{ Performance Indicators } & \multirow[t]{2}{*}{ Agree } & \multirow[t]{2}{*}{ Disagree } & \multicolumn{3}{|c|}{ Importance Rating } & \multirow{2}{*}{$\begin{array}{l}\text { Level of } \\
\text { Importance }\end{array}$} & \multirow{2}{*}{$\begin{array}{l}\text { Ref. } \\
\text { (Similar findings } \\
\text { by other authors) }\end{array}$} \\
\hline & & & & $\begin{array}{l}\text { RII } \\
100 \%\end{array}$ & $\begin{array}{l}\text { Mean } \\
\text { value }\end{array}$ & StDev. & & \\
\hline & \multicolumn{8}{|c|}{ Investigation and Reporting of accident } \\
\hline 1 & $\begin{array}{l}\text { Utilization of safety } \\
\text { reports for improvement } \\
\text { of safety performance }\end{array}$ & 11 & & 69.09 & 3.45 & 0.69 & VI & (Wu et al., 2016) \\
\hline 2 & $\begin{array}{l}\text { Near misses are } \\
\text { investigated to prevent } \\
\text { future site incidents }\end{array}$ & 11 & & 80.00 & 4.18 & 0.98 & VI & \multirow{3}{*}{$\begin{array}{l}\text { (Asanka \& } \\
\text { Ranasinghe, 2016; } \\
\text { Umeokafor et al., } \\
2014 \text { ) }\end{array}$} \\
\hline 3 & $\begin{array}{l}\text { Near misses are reported in } \\
\text { the incident logs }\end{array}$ & 11 & & 100 & 5.00 & 0.00 & EI & \\
\hline 4 & $\begin{array}{l}\text { Appropriate procedures to } \\
\text { prevent recurrence of } \\
\text { accidents }\end{array}$ & 11 & & 80.00 & 4.00 & 1.09 & VI & \\
\hline 5 & $\begin{array}{l}\text { Record keeping of accident } \\
\text { and incident logs have ease } \\
\text { of access }\end{array}$ & 11 & & 78.18 & 3.91 & 0.94 & VI & \multirow{2}{*}{$\begin{array}{l}\text { (Hallowell \& } \\
\text { Gambatese, 2009; } \\
\text { Kartam, Flood \& } \\
\text { Koushki, 2000) }\end{array}$} \\
\hline 6 & $\begin{array}{l}\text { Keep a record of accidents } \\
\text { and incidents of the } \\
\text { contractors and } \\
\text { subcontractors. }\end{array}$ & 11 & & 74.55 & 3.73 & 0.46 & VI & \\
\hline
\end{tabular}




\begin{tabular}{|c|c|c|c|c|c|c|c|c|}
\hline \multirow[t]{2}{*}{ S/No } & \multirow[t]{2}{*}{ Performance Indicators } & \multirow[t]{2}{*}{ Agree } & \multirow[t]{2}{*}{ Disagree } & \multicolumn{3}{|c|}{ Importance Rating } & \multirow{2}{*}{$\begin{array}{c}\text { Level of } \\
\text { Importance }\end{array}$} & \multirow{2}{*}{$\begin{array}{l}\text { Ref. } \\
\text { (Similar findings } \\
\text { by other authors) }\end{array}$} \\
\hline & & & & $\begin{array}{l}\text { RII } \\
100 \%\end{array}$ & $\begin{array}{l}\text { Mean } \\
\text { value }\end{array}$ & StDev. & & \\
\hline 7 & $\begin{array}{l}\text { Review and audit safety } \\
\text { procedures used by the } \\
\text { contractor }\end{array}$ & 11 & & 81.82 & 4.36 & 0.67 & VI & \multirow{2}{*}{$\begin{array}{l}\text { (Khosravi et al., } \\
\text { 2014) }\end{array}$} \\
\hline 8 & $\begin{array}{l}\text { Occasionally audits } \\
\text { contractor safety } \\
\text { procedures and operations. }\end{array}$ & 11 & & 80.00 & 4.00 & 0.44 & VI & \\
\hline
\end{tabular}

Table 9. Key Performance Indicators for Investigation and Reporting of accident

\subsection{Rewards and Sanctions for Project Stakeholders}

Results in Table 10 indicate that respondents agree to the inclusion of all the KPIs except two or three respondents that disagreed. However, the KPI "appropriate penalty in the form of reporting to relevant law enforcement authorities" and "provision of penalty in the form of rank demotion" had almost all the respondents disagreed, which were perceived as "somewhat important" (with RII values 53.33\% and 32.73\% respectively) this clearly indicate the non-inclusion of the KPIs in reducing construction accidents. Furthermore, two of the KPIs were perceived as "extremely important' "provision of rewards for good safety performance" with RII of $96.36 \%$ and "availability of reward in the form of certificate of corporate recognition" with RII of 98.18\%. Table 10 also shows similar findings by other researchers.

\begin{tabular}{|c|c|c|c|c|c|c|c|c|}
\hline \multirow[t]{2}{*}{ S/No } & \multirow[t]{2}{*}{ Performance Indicators } & \multirow[t]{2}{*}{ Agree } & \multirow[t]{2}{*}{ Disagree } & \multicolumn{3}{|c|}{ Importance Rating } & \multirow{2}{*}{$\begin{array}{l}\text { Level of } \\
\text { Importance }\end{array}$} & \multirow{2}{*}{$\begin{array}{l}\text { Ref. } \\
\text { (Similar findings } \\
\text { by other authors) }\end{array}$} \\
\hline & & & & $\begin{array}{c}\text { RII } \\
100 \%\end{array}$ & $\begin{array}{l}\text { Mean } \\
\text { value }\end{array}$ & StDev. & & \\
\hline & \multicolumn{8}{|c|}{ Rewards and Sanctions for Project Stakeholders } \\
\hline 1 & $\begin{array}{l}\text { Penalties are spelt out for } \\
\text { dissatisfactory safety } \\
\text { performance }\end{array}$ & 8 & 3 & 70.91 & 3.64 & 0.92 & VI & $\begin{array}{l}\text { (Teo, Ling \& Ong, } \\
\text { 2005) }\end{array}$ \\
\hline 2 & $\begin{array}{l}\text { Provision of rewards for } \\
\text { good safety performance }\end{array}$ & 11 & & 96.36 & 4.81 & 0.40 & EI & \multirow{8}{*}{$\begin{array}{l}\text { (Alarcón et al., } \\
\text { 2016; Arditi, } \\
\text { Yasamis \& } \\
\text { Member, 1998; } \\
\text { Ashworth, 2013; } \\
\text { Choi \& Kwak, } \\
\text { 2012; Hu et al., } \\
\text { 2012; Rose \& } \\
\text { Manley, 2011) }\end{array}$} \\
\hline 3 & $\begin{array}{l}\text { Provision of sanctions and } \\
\text { penalties }\end{array}$ & 8 & 3 & 74.55 & 3.73 & 1.10 & VI & \\
\hline 4 & $\begin{array}{l}\text { Provision of penalty in } \\
\text { form of work stoppage }\end{array}$ & 10 & 1 & 76.36 & 3.62 & 0.92 & VI & \\
\hline 5 & $\begin{array}{l}\text { Provision of reward in } \\
\text { form monetary bonus }\end{array}$ & 8 & 3 & 70.91 & 3.55 & 0.82 & VI & \\
\hline 6 & $\begin{array}{l}\text { Availability of reward in } \\
\text { form of certificate of } \\
\text { corporate recognition }\end{array}$ & 11 & & 98.18 & 4.91 & 0.30 & EI & \\
\hline 7 & $\begin{array}{l}\text { Provision of reward in the } \\
\text { form of rank elevation }\end{array}$ & 11 & & 80.00 & 4.00 & 0.44 & VI & \\
\hline 8 & $\begin{array}{l}\text { The appropriate penalty in } \\
\text { the form of reporting to } \\
\text { relevant law enforcement } \\
\text { authorities }\end{array}$ & 2 & 9 & 53.33 & 3.00 & 0.89 & SI & \\
\hline 9 & $\begin{array}{l}\text { Provision of penalty in } \\
\text { form of rank demotion }\end{array}$ & 3 & 8 & 32.73 & 1.64 & 0.92 & SI & \\
\hline
\end{tabular}




\begin{tabular}{|c|c|c|c|c|c|c|c|c|}
\hline \multirow[t]{2}{*}{ S/No } & \multirow[t]{2}{*}{ Performance Indicators } & \multirow[t]{2}{*}{ Agree } & \multirow[t]{2}{*}{ Disagree } & \multicolumn{3}{|c|}{ Importance Rating } & \multirow{2}{*}{$\begin{array}{l}\text { Level of } \\
\text { Importance }\end{array}$} & \multirow{2}{*}{$\begin{array}{c}\text { Ref. } \\
\text { (Similar findings } \\
\text { by other authors) }\end{array}$} \\
\hline & & & & $\begin{array}{c}\text { RII } \\
100 \%\end{array}$ & $\begin{array}{l}\text { Mean } \\
\text { value }\end{array}$ & StDev. & & \\
\hline 10 & $\begin{array}{l}\text { Established penalty in } \\
\text { form of disengagement } \\
\text { from work }\end{array}$ & 9 & 2 & 69.09 & 3.45 & 0.68 & VI & \\
\hline 11 & $\begin{array}{l}\text { Availability of monetary } \\
\text { fines and penalty }\end{array}$ & 11 & & 81.82 & 4.09 & 0.70 & VI & \\
\hline
\end{tabular}

Table 10. Key Performance Indicators for Rewards and Sanctions for project stakeholders

\section{Discussions and Conclusions}

Key performance indicators refer to a tool used to assess the efficiency of construction facilities. Such KPIs differ in relation to the reason of the assessment and typology of facility being examined. Kylili, Fokaides and López-Jiménez (2016) among other researchers also identified their effectiveness in the assessment of building construction performance. Despite existing research in the area of construction safety, there is no established KPIs that could be used to reliably assess or promote building developer safety performance.

This study, established 137 KPIs that can be deployed for promoting or assessing building developer's safety performance in the construction industry in Nigeria. In-depth review of the literature supported by evaluation from 11 subject matter experts and professionals that validated and ensure clarity and inclusion. The KPIs were further categorized into 9 categories that include: Planning, design and procurement. Construction safety policy, construction safety personnel, communication \& maintenance of effective safety behavior, management effort and support, safety training and orientation, administration of safety processes, accident reporting and investigation, rewards and sanctions for project stakeholders. The categorization was used as a basis of presenting the KPIs to show the response of survey conducted on 11 respondents. The survey required the respondents to either agree/disagree with statements and rank the KPIs by their perceived relevance.

Results from the focus group discussion revealed that the respondents consider all the KPIs important, even as some of the KPIs are rated less important, compared to the ones perceived to be "extremely important". Thus, factors such as "Near misses are reported in the incident logs", "Availability of reward in form of certificate of corporate recognition" "Involvement of the building developer at all project phases" with RII value of 100\%, 98\%, and $93 \%$ respectively to be extremely important. Also, "language and communication challenges by workers are adequately resolved before work start" with an RII value of 100\%, "establishing relevant policies, standards and safe work practices necessary to address worker safety" with an RII value of 100\% are among the KPIs considered extremely important. Some KPIs is perceived to be "important" by the respondents include: "SMS implementation", "accident cases reported on a site influence the number of safety personnel deployed to the site" (RII of 51\%), "conduct safety orientation for all site visitors is required by the safety program", (RII of 51\%). Moreover, "safety program requires emergency response drills" (RII of 45\%), is among the KPIs considered "important". Also, other KPIs perceived to be as "somewhat not important" such as "top management directly takes part in the enforcement of safety on sites" RII of 35\%, "appropriate penalty in the form of reporting to relevant law enforcement authorities" RII of 53\%.

The established KPIs therefore, presents a guideline to ensure safety performance of construction stakeholders in the construction industry in Nigeria. The guideline would be of much use to building developers, research institutions, Architects, Contractors and professionals involved in building construction in Nigeria. The study would also encourage further research into the KPIs of other construction types. It is worthy of note that much care was taken to establish all possible KPIs for building developer, however, citation of some relevant literature may have been omitted, or some KPIs may still look uncaptured to the perception of the reader. Finally, implementation of the established KPIs in the form of measurement tool on real-life case studies would be the target of future research work to show the application of the KPIs in assessment of construction safety performance of building developers in Nigeria. 


\section{Declaration of Conflicting Interests}

The authors have declared no potential conflicts of interest with respect to the research, authorship, and/or publication of this article.

\section{Funding}

The authors received no financial support for the research, authorship, and/or publication of this article.

\section{References}

Abudayyeh, O., Fredericks, T.K., Butt, S.E., \& Shaar, A. (2006). An investigation of management's commitment to construction safety. International Journal of Project Management, 24(2), 167-174.

https://doi.org/10.1016/j.ijproman.2005.07.005

Agwu, M. (2012). Total Safety Management: A Strategy for Improving Organisational Performance in Chosen Construction Companies in Nigeria. International Journal of Business and Social Science.

https://doi.org/10.9734/BJEMT/2012/1317

Agwu, M.O., \& Olele, H.E. (2014). Fatalities in the Nigerian Construction Industry: A case of poor safety culture. British Journal of Economics, Management \& Trade, 4(3), 431-452. https://doi.org/10.9734/BJEMT/2014/6439

Ajayi, R. (2016). Evaluation of Health and Safety Planning Process on Construction Sites in Kaduna Metropolis, Nigeria. $399-408$.

Aksorn, T., \& Hadikusumo, B.H.W. (2008). Critical success factors influencing safety program performance in Thai construction projects. Safety Science, 46(4), 709-727. https://doi.org/10.1016/j.ssci.2007.06.006

Alarcón, L.F., Acuña, D., Diethelm, S., \& Pellicer, E. (2016). Strategies for improving safety performance in construction firms. Accident Analysis \& Prevention, 94, 107-118. https://doi.org/10.1016/j.aap.2016.05.021

Ali, A.S., Kamaruzzaman, S.N., \& Sing, G.C. (2010). A Study On Causes Of Accident And Prevention In Malaysian Construction Industry. Journal of Design + Build.

Alzahrani, J.I., \& Emsley, M.W. (2013). The impact of contractors' attributes on construction project success: A post construction evaluation. International Journal of Project Management.

https://doi.org/10.1016/j.ijproman.2012.06.006

American Society of Civil Engineers-ASCE (2012). Quality in the Constructed Project: a Guide for Owners, Designers and Constructors. https://doi.org/10.1061/9780784411896

Aniekwu, N. (2007). Accidents and safety Violations in the Nigerian construction industry. Journal of science and technology, 27, 81). https://doi.org/10.4314/just.v27i1.33027

Anumba, C. (1999). Concurrent Engineering in Construction - An Opportunity to Improve Construction Safety; Implementation of Safety and Health on Construction Sites. Proceedings of the 2nd International Conference of the CIB Working Commission; Honolulu, HA; March 24- 27; pp. 157-164

Arditi, D., Yasamis, F., \& Member, S. (1998). of Owners and Contractors. Engineering, 124, 361-373. https://doi.org/10.1061/(ASCE)0733-9364(1998)124:5(361)

Arezes, P.M., \& Sérgio-Miguel, A. (2003). The role of safety culture in safety performance measurement. Measuring Business Excellence. https://doi.org/10.1108/13683040310509287

Asanka, W.A., \& Ranasinghe, M. (2016). Distribution of Responsibilities and Applicability of Risk Assessments in Construction Safety. Annual Sessions of IESL, 455-463.

Ashworth, A. (2013). Contractual procedures in the construction industry, sixth edition. In Contractual Procedures in the Construction Industry (6th ed.). https://doi.org/10.4324/9781315847061 
Ayob, A., Shaari, A.A., Zaki, M.F.M., \& Munaaim, M.A.C. (2018). Fatal Occupational Injuries in the Malaysian Construction Sector - Causes and Accidental Agents. Earth and Environmental Science PAPER. https://doi.org/10.1088/1755-1315/140/1/012095

Barling, J., \& Hutchinson, I. (2009). Commitment vs. Control-based Safety Practices, Safety Réputation, and Perceived Safety Climate. Canadian Journal of Administrative Sciences / Revue Canadienne Des Sciences de l'Administration. https://doi.org/10.1111/j.1936-4490.2000.tb00208.x

Bello, M.A. (2012). Minimizing Impediments to Design for Construction Safety (DFCS) Implementation on Capital Projects. Dissertation.

Biggs, H.C., \& Biggs, S.E. (2013). Interlocked projects in safety competency and safety effectiveness indicators in the construction sector. Safety Science, 52, 37-42. https://doi.org/10.1016/j.ssci.2012.03.014

Biswas, G., Bhattacharya, A., \& Bhattacharya, R. (2017). Occupational health status of construction workers: A review. International Journal of Medical Science and Public Health, 6(4), 1. https://doi.org/10.5455/ijmsph.2017.0745302112016

Boyd, M. (2014). Recruiting high skill labour in north america: Policies, outcomes and futures. International Migration. https://doi.org/10.1111/imig.12139

Chan, A.P.C., \& Chan, A.P.L. (2004). Key performance indicators for measuring construction success. In Benchmarking. https://doi.org/10.1108/14635770410532624

Charehzehi, A., \& Ahankoob, A. (2012). Enhancement of safety performance at construction site. International Journal of Advances in Engineering \& Technology. https://doi.org/10.4038/engineer.v48i3.6840

Cheng, C.W., \& Wu, T.C. (2013). An investigation and analysis of major accidents involving foreign workers in Taiwan's manufacture and construction industries. Safety Science, 57, 223-235. https://doi.org/10.1016/j.ssci.2013.02.008

Chi, C.F., Chang, T.C., \& Ting, H.I. (2005). Accident patterns and prevention measures for fatal occupational falls in the construction industry. Applied Ergonomics, 36(4 spec.), 391-400. https://doi.org/10.1016/j.apergo.2004.09.011

Choe, S., \& Leite, F. (2017). Construction safety planning: Site-specific temporal and spatial information integration. Automation in Construction. https://doi.org/10.1016/j.autcon.2017.09.007

Choi, K., \& Kwak, Y.H. (2012). Decision support model for incentives/disincentives time-cost tradeoff. Automation in Construction. https://doi.org/10.1016/j.autcon.2011.06.006

Choudhry, R.M. (2014). Behavior-based safety on construction sites: A case study. Accident Analysis and Prevention, 70 , 14-23. https://doi.org/10.1016/j.aap.2014.03.007

Choudhry, R.M., \& Fang, D. (2008). Why operatives engage in unsafe work behavior: Investigating factors on construction sites. Safety Science. https://doi.org/10.1016/j.ssci.2007.06.027

Choudhry, R.M., Fang, D., \& Mohamed, S. (2007). Developing a Model of Construction Safety Culture. Journal of Management in Engineering. https://doi.org/10.1061/(ASCE)0742-597X(2007)23:4(207)

Choudhry, R.M., Fang, D., \& Rowlinson, S. (2008). Challenging and Enforcing Safety Management in Developing Countries: A Strategy. International Journal of Construction Management. https://doi.org/10.1080/15623599.2008.10773110

Chuks, O.K., \& Uchenna, P. (2012). Appraising the Influence of Cultural Determinants of Contruction Workers Safety Perceptionand Behaviour in Nigeria. March 2013, 11-24.

Construction Industry Institute - CII (2003). Value of best practices report. Rep. No. BMM 2003-4, Construction Industry Institute, The Univ. of Texas at Austin, Austin, Tex.

Construction Industry Institute - CII (2015). Successful Delivery of Mega-Projects. CII Annual Conference. 
CPWR (2008). The construction chart book: the U.S. construction industry and its workers (Issue April). Available at: www.cpwr.com

De Silva, N., \& Wimalaratne, P.L.I. (2012). OSH management framework for workers at construction sites in Sri Lanka. Engineering, Construction and Architectural Management, 19(4), 369-392. https://doi.org/10.1108/09699981211237094

Delegach, M., Kark, R., Katz-Navon, T., \& van Dijk, D. (2017). A focus on commitment: the roles of transformational and transactional leadership and self-regulatory focus in fostering organizational and safety commitment. European Journal of Work and Organizational Psychology. https://doi.org/10.1080/1359432X.2017.1345884

Dingsdag, D.P., Biggs, H.C., \& Sheahan, V.L. (2008). Understanding and defining OH\&S competency for construction site positions: Worker perceptions. Safety Science, 46(4), 619-633.

https://doi.org/10.1016/j.ssci.2007.06.008

Diugwu, I.A., \& Baba, D.L. (2014). A Health and Safety Improvement Roadmap for the Construction Industry. https://doi.org/10.6106/JCEPM.2014.4.1.037

Dodo, M. (2012). Best practices for optimizing DOD contractor safety and occupational health program performance. December.

Dominowski, R.L. (1980). Research methods. Prentice-Hall.

El-Nagar, R., Hosny, H., \& Askar, H.S. (2015). Development of a safety performance index for construction projects in Egypt. American Journal of Civil Engineering and Architecture, 3(5), 182-192.

Elliott, J. (2016). Safety I and safety II: the past and future of safety management. Ergonomics. https://doi.org/10.1080/00140139.2015.1093290

European Foundation for the Improvement of Living and Working Conditions (1991). From Drawing Board to Building Site (EF/88/17/FR): Dublin, Ireland.

Ezenwa, A.O. (2001). A study of fatal injuries in Nigerian factories. Occupational Medicine. https://doi.org/10.1093/occmed/51.8.485

Fang, D., \& Wu, H. (2013). Development of a Safety Culture Interaction (SCI) model for construction projects. Safety Science, 57, 138-149. https://doi.org/10.1016/j.ssci.2013.02.003

Farooqui, R.U. (2011). Achieving Zero Accidents - A Strategic Framework for Continuous Safety Improvement in the Construction Industry. https:// doi.org/10.25148/etd.FI11050608

Fass, S., Yousef, R., Liginlal, D., \& Vyas, P. (2017). Understanding causes of fall and struck-by incidents: What differentiates construction safety in the Arabian Gulf region? Applied Ergonomics, 58, 515-526. https://doi.org/10.1016/j.apergo.2016.05.002

Filstad, C. (2011). Organizational commitment through organizational socialization tactics. Journal of Workplace Learning. https://doi.org/10.1108/13665621111154395

Findley, M., Smith, S., Kress, T., Petty, G., \& Enoch, K. (2004). Safety Program Elements in Construction. Professional Safety, 49(2), 14-21. http://libproxy.unm.edu/login?url=http://search.ebscohost.com/login.aspx? direct $=$ true $\& \mathrm{db}=\mathrm{a} 9 \mathrm{~h} \& \mathrm{AN}=12136203 \& \log$ inpage $=$ Login. asp \&scope $=$ site

Fonseca, E.D., Lima, F.P.A., \& Duarte, F. (2014). From construction site to design: The different accident prevention levels in the building industry. Safety Science, 70, 406-418. https://doi.org/10.1016/j.ssci.2014.07.006

Funso, A., Sammy, L., \& Gerryshom, M. (2016). Impact of Motivation on Productivity of Craftsmen in Construction Firms in Lagos, Nigeria. International Journal of Economics and Finance, 8(4), 271. https://doi.org/10.5539/ijef.v8n4p271

Gambatese, J.A., Behm, M., \& Hinze, J.W. (2005). Viability of Designing for Construction Worker Safety, 131(9), 10291036. https://doi.org/10.1061/(ASCE)0733-9364(2005)131:9(1029) 
Gambatese, J.A., Asce, M., Toole, T.M., Asce, F., Abowitz, D.A., Asce, M. et al. (2017). Owner Perceptions of Barriers to Prevention through Design Diffusion. Journal of Construction Engineering and Management. https://doi.org/10.1061/(ASCE)CO.1943-7862.0001296

Gambatese, J.A., Behm, M., \& Rajendran, S. (2008). Design's role in construction accident causality and prevention: Perspectives from an expert panel. Safety Science. https://doi.org/10.1016/j.ssci.2007.06.010

Gambatese, J., \& Hinze, J. (1999). Addressing construction worker safety in the design phase designing for construction worker safety. Automation in Construction. https://doi.org/10.1016/S0926-5805(98)00109-5

Gambatese, J.A. (2000). Owner involvement in construction site safety. Construction Congress. https://doi.org/10.1061/40475(278)71

Ghasemi, F., Mohammadfam, I., Soltanian, A.R., Mahmoudi, S., \& Zarei, E. (2015). Surprising incentive: An instrument for promoting safety performance of construction employees. Safety and Health at Work. https://doi.org/10.1016/j.shaw.2015.02.006

Gu, C., \& Yang, Y. (2015). Incentive mechanism for customer collaboration in product development: An exploratory study. Journal of Industrial Engineering and Management. https://doi.org/10.3926/jiem.1603

Gunduz, M., Birgonul, M.T., \& Ozdemir, M. (2017). Fuzzy Structural Equation Model to Assess Construction Site Safety Performance. Journal of Construction Engineering \& Management. https:/ / doi.org/10.1061/(ASCE)CO.19437862.0001259

Hale, A. (2009). Why safety performance indicators? Safety Science, 47(4), 479-480. https://doi.org/10.1016/j.ssci.2008.07.018

Hale, A., \& Borys, D. (2013). Working to rule or working safely? Part 2: The management of safety rules and procedures. In Safety Science. https://doi.org/10.1016/j.ssci.2012.05.013

Hallowell, M.R., \& Gambatese, J.A. (2009). Construction Safety Risk Mitigation. Journal of Construction Engineering \& Management, 135(December), 1316-1323. https://doi.org/10.1061/(ASCE)CO.1943-7862.0000107

Hallowell, M.R., \& Hansen, D. (2016). Measuring and improving designer hazard recognition skill: Critical competency to enable prevention through design. Safety Science, 82, 254-263.

https://doi.org/10.1016/j.ssci.2015.09.005

Hare, B., \& Cameron, I. (2012). Health and safety gateways for construction project planning. Engineering, Construction and Architectural Management. https://doi.org/10.1108/09699981211206115

Hare, B., Cameron, I., \& Duff, A.R. (2006). Exploring the integration of health and safety with pre-construction planning. Engineering, Construction and Architectural Management. https://doi.org/10.1108/09699980610690729

Haslam, R.A., Hide, S.A., Gibb, A.G.F., Gyi, D.E., Pavitt, T., Atkinson, S. et al. (2005). Contributing factors in construction accidents. Applied Ergonomics, 36(4 spec.), 401-415. https://doi.org/10.1016/j.apergo.2004.12.002

Hassanain, M.A., Sanni-Anibire, M.O., Mahmoud, A.S., \& Hamida, M.B. (2019). Design guidelines for the functional efficiency of laboratory facilities. Architectural Engineering and Design Management. https://doi.org/10.1080/17452007.2019.1675580

Helix ESG (2003). Permit to work. In Permit to Work System. https://doi.org/10.1205/026095703770045474

Herrera, I. (2012). Proactive safety performance indicators, resilience engineering perspective on safety management. Doctoral Thesis. Norwegian University of Science and Technology, Norway. PhD Thesis, 12, 123-9.

Hinze, J. (2002). Safety Incentives: Do They Reduce Injuries? Practice Periodical on Structural Design and Construction. https://doi.org/10.1061/(ASCE)1084-0680(2002)7:2(81)

Hinze, J., Asce, M., Hallowell, M., Asce, A.M., \& Baud, K. (2013). Construction-Safety Best Practices and Relationships to Safety Performance, 139(10), 1-8. https://doi.org/10.1061/(ASCE)CO.1943-7862.0000751 
Hinze, J., \& Gambatese, J. (2003). Factors That Influence Safety Performance of Specialty Contractors. Journal of Construction Engineering and Management, 129(2), 159-164. https://doi.org/10.1061/(ASCE)0733-9364(2003)129:2(159)

Hinze, J., Hallowell, M., \& Baud, K. (2013). Construction-Safety Best Practices and Relationships to Safety Performance. Journal of Construction Engineering and Management. https://doi.org/10.1061/(ASCE)CO.19437862.0000751

Hinze, J.W. (2000). Moving toward a Zero Injury Objective. Journal Construction and Engineering Management. ttps://doi.org/10.1061/(ASCE)0733-9364(2000)126:5(399)

Hu, Y., Chan, A.P.C., Le, Y., Jiang, W.P., Xie, L.L., \& Hon, C.H.K. (2012). Improving Megasite Management Performance through Incentives: Lessons Learned from the Shanghai Expo Construction. Journal of Management in Engineering. https:// doi.org/10.1061/(ASCE)ME.1943-5479.0000102

Huang, C., \& Wong, C.K. (2015). Optimisation of site layout planning for multiple construction stages with safety considerations and requirements. Automation in Construction. https://doi.org/10.1016/j.autcon.2015.03.005

Huang, X., \& Hinze, J. (2006). Owner's Role in Construction Safety. Journal of Construction Engineering and Management, February, 164-173. https://doi.org/10.1061/(ASCE)0733-9364(2006)132:2(164)

Huang, Y., Verma, S.K., Chang, W., Courtney, T.K., Lombardi, D.A., Brennan, M.J. et al. (2012). Management commitment to safety vs . employee perceived safety training and association with future injury. Accident Analysis and Prevention, 47(2012), 94-101. https://doi.org/10.1016/j.aap.2011.12.001

Idoro, G.I. (2008). Health and safety management efforts as correlates of performance in the Nigerian construction industry. Journal of Civil Engineering and Management, 14(4), 277-285. https://doi.org/10.3846/1392-3730.2008.14.27

Idoro, G.I. (2012). Influence of the monitoring and control strategies of indigenous and expatriate nigerian contractors on project outcome. Journal of Construction in Developing Countries.

International Labour Organization - ILO (1995). Safety, health and welfare on construction sites: A training manual. International Labour Organization.

Inuwa, I.I., Githae, W., \& Diang, S. (2014). Indigenous Contractors Involvement and Performance in Construction Procurement Systems in Nigeria. Global Journal of Researches in Engineering: General Engineering, 14(1), 13.

Jannadi, O.A., \& Almishari, S. (2003). Risk Assessment in Construction. Journal of Construction Engineering and Management, 129(5), 492-500. https://doi.org/10.1061/(ASCE)0733-9364(2003)129:5(492)

Jaraiedi, M., Plummer, R.W., \& Aber, M.S. (1995). Incentive/disincentive guidelines for highway construction contracts. Journal of Construction Engineering and Management, 121(1), 112-120. https://doi.org/10.1061/(ASCE)07339364(1995)121:1(112)

Jaselskis, E.J., Anderson, S.D., \& Russell, J.S. (1996). Strategies for achieving excellence in construction safety performance. Journal of Construction Engineering and Management. https://doi.org/10.1061/(ASCE)07339364(1996)122:1(61)

Jazayeri, E., Liu, H., \& Dadi, G.B. (2017). Perception Differences between Contractors and Owners Regarding Drivers of Construction Safety, 6(2), 29-39. https://doi.org/10.5923/j.safety.20170602.02

Jensen, P.L., Laustsen, S., \& Jensen, E. (2016). Development of the Relationship Between Small Building Contractors and Developers in Order to Meet OSH Requirements. Policy and Practice in Health and Safety, 8(2), 37-55. https://doi.org/10.1080/14774003.2010.11667747

Kadiri, Z.O., Nden, T., Avre, G.K., Oladipo, T.O., Edom, A., Samuel, P.O., \& Ananso, G.N. (2014). Causes and Effects of Accidents on Construction Sites (A Case Study of Some Selected Construction Firms in Abuja FCT Nigeria). IOSR Journal of Mechanical and Civil Engineering (IOSR-JMCE).

Karakhan, A.A., \& Gambatese, J.A. (2017). Identification, Quantification, and Classification of Potential Safety Risk for Sustainable Construction in the United States. Journal of Construction Engineering and Management, 143(7). https://doi.org/10.1061/(ASCE)CO.1943-7862.0001302 
Kartam, N.A., Flood, I., \& Koushki, P. (2000). Construction safety in Kuwait: Issues, procedures, problems, and recommendations. In Safety Science. https://doi.org/10.1016/S0925-7535(00)00041-2

Khosravi, Y., Asilian-Mahabadi, H., Hajizadeh, E., Hassanzadeh-Rangi, N., Bastani, H., \& Behzadan, A.H. (2014). Factors influencing unsafe behaviors and accidents on construction sites: A review. International Journal of Occupational Safety and Ergonomics, 20(1), 111-125. https://doi.org/10.1080/10803548.2014.11077023

Kim, S.S., Yang, I.H., Yeo, M.S., \& Kim, K.W. (2005). Development of a housing performance evaluation model for multi-family residential buildings in Korea. Building and Environment. https://doi.org/10.1016/j.buildenv.2004.09.014

Kylili, A., Fokaides, P.A., \& López-Jiménez, P.A. (2016). Key Performance Indicators (KPIs) approach in buildings renovation for the sustainability of the built environment: A review. In Renewable and Sustainable Energy Reviens. https://doi.org/10.1016/j.rser.2015.11.096

Lavy, S., Garcia, J.A., \& Dixit, M.K. (2014a). KPIs for facility's performance assessment, Part I: Identification and categorization of core indicators. Facilities. https://doi.org/10.1108/F-09-2012-0066

Lavy, S., Garcia, J.A., \& Dixit, M.K. (2014b). KPIs for facility's performance assessment, Part II: Identification of variables and deriving expressions for core indicators. Facilities. https://doi.org/10.1108/F-09-2012-0067

Ling, F.Y.Y., Liu, M., \& Woo, Y.C. (2009). Construction fatalities in Singapore. International Journal of Project Management. https://doi.org/10.1016/j.ijproman.2008.11.002

Luo, Y., \& van den Brand, M. (2016). Metrics design for safety assessment. Information and Software Technology, 73, 151-163. https://doi.org/10.1016/j.infsof.2015.12.012

Mahmoud, A.S., Sanni-Anibire, M.O., Hassanain, M.A., \& Ahmed, W. (2019). Key performance indicators for the evaluation of academic and research laboratory facilities. International Journal of Building Pathology and Adaptation, 37(2), 208-230. https://doi.org/10.1108/IJBPA-08-2018-0066

Manu, P., Ankrah, N., Proverbs, D., \& Suresh, S. (2013). Mitigating the health and safety influence of subcontracting in construction: The approach of main contractors. International Journal of Project Management. https://doi.org/10.1016/j.ijproman.2012.11.011

Michael, J.H., Evans, D.D., Jansen, K.J., \& Haight, J.M. (2005). Management commitment to safety as organizational support: Relationships with non-safety outcomes in wood manufacturing employees. 36, 171-179. https://doi.org/10.1016/j.jsr.2005.03.002

Misiurek, K., \& Misiurek, B. (2017). Methodology of improving occupational safety in the construction industry on the basis of the TWI program. Safety Science, 92. https://doi.org/10.1016/j.ssci.2016.10.017

Molenaar, K.R., Park, J.I., \& Washington, S. (2009). Framework for Measuring Corporate Safety Culture and Its Impact on Construction Safety Performance. Journal of Construction Engineering and Management. https://doi.org/10.1061/(ASCE)0733-9364(2009)135:6(488)

Mudi, A., Bioku, J., \& Kolawole, O. (2015). Assessing the Characteristics of Nigerian Construction Industry in Infrastructure Development. International Journal of Engineering Research \& Tecbnology (IJERT), 4(11), 546-555.

Muiruri, G., \& Mulinge, C. (2014). Health and Safety Management on Construction Projects Sites in Kenya A Case Study of Construction Projects in Nairobi County. FIG Congress 2014 - Engaging the Challenges - Enhancing the Relevance Kuala Lumpur (14). Malaysia 16-21 June, 14.

Mustapha, Z., Aigbavboa, C., \& Thwala, W. (2017). Contractor health and safety compliance for small to mediumsized construction companies. In Contractor Health and Safety Compliance for Small to Medium-Sized Construction Companies. https://doi.org/10.1201/b22259

Odeyinka, H.A. (2000). An evaluation of the use of insurance in managing construction risks. Construction Management and Economics. https://doi.org/10.1080/014461900407329 
Øien, K., Utne, I.B., Tinmannsvik, R.K., \& Massaiu, S. (2011). Building Safety indicators: Part 2 - Application, practices and results. Safety Science, 49(2), 162-171. https://doi.org/10.1016/j.ssci.2010.05.015

Okoro, C.S., Musonda, I., \& Agumba, J. (2017). Identifying Determinants of Construction Worker Performance on Construction Sites: A Literature Review. International Journal of Innovation, Management and Technology, 8(1), 60-64. https://doi.org/10.18178/ijimt.2017.8.1.703

Okoye, P.U., Ezeokonkwo, J.U., \& Ezeokoli, F.O. (2016). Building Construction Workers ' Health and Safety Knowledge and Compliance on Site. Journal of Safety Engineering, 5(1), 17-26. https://doi.org/10.5923/j.safety.20160501.03

Okoye, P.U., Mbakwe, C.C., \& Igbo, E.N. (2018). Modeling the construction sector and oil prices toward the growth of the Nigerian economy: An econometric approach. Economies. https://doi.org/10.3390/economies6010016

OSHA (2015). Training Requirements in OSHA Standards and Training Guidelines. Safety And Health. https://doi.org/10.1016/j.fcr.2015.03.010

Park, C.S., \& Kim, H.J. (2013). A framework for construction safety management and visualization system. Automation in Construction. https://doi.org/10.1016/j.autcon.2012.09.012

Preiser, W.F.E., Rabinowitz, H.Z.E., \& White, E.T. (1987). Post Occupancy Evaluation. New York: Van Nostrand Reainhold Comp.

Reiman, T., \& Pietikäinen, E. (2012). Leading indicators of system safety - Monitoring and driving the organizational safety potential. Safety Science, 50(10), 1993-2000. https://doi.org/10.1016/j.ssci.2011.07.015

Rose, T., \& Manley, K. (2011). Motivation toward financial incentive goals on construction projects. Journal of Business Research, 64(7), 765-773. https://doi.org/10.1016/j.jbusres.2010.07.003

Sacks, R., Perlman, A., \& Barak, R. (2013). Construction safety training using immersive virtual reality. Construction Management and Economics. https://doi.org/10.1080/01446193.2013.828844

Sadeghi, L., Mathieu, L., Tricot, N., \& Al Bassit, L. (2015). Developing a safety indicator to measure the safety level during design for safety. Safety Science, 80, 252-263. https://doi.org/10.1016/j.ssci.2015.08.006

Saifullah, N.M., \& Ismail, F. (2012). Integration of Occupational Safety and Health during Pre-construction Stage in Malaysia. Procedia - Social and Behavioral Sciences. https://doi.org/10.1016/j.sbspro.2012.02.127

Saurin, T.A. (2016). Safety inspections in construction sites: A systems thinking perspective. In Accident Analysis and Prevention. https://doi.org/10.1016/j.aap.2015.10.032

Shea, T., De Cieri, H., Donohue, R., Cooper, B., \& Sheehan, C. (2016). Leading indicators of occupational health and safety: An employee and workplace level validation study. Safety Science, 85. https://doi.org/10.1016/j.ssci.2016.01.015

Shen, Y., Ju, C., Koh, T.Y., Rowlinson, S., \& Bridge, A.J. (2017). The impact of transformational leadership on safety climate and individual safety behavior on construction sites. International Journal of Environmental Research and Public Health, 14(1), 1-17. https://doi.org/10.3390/ijerph14010045

Sinelnikov, S., Inouye, J., \& Kerper, S. (2015). Using leading indicators to measure occupational health and safety performance. Safety Science, 72, 240-248. https://doi.org/10.1016/j.ssci.2014.09.010

Smallwood, J.J. (2002). The Influence of Health and Safety (H \& S) Culture on H \& S Performance. In: Greenwood, D. (Ed.), Proceedings 18th Annual ARCOM Conference, Association of Researchers in Construction Management, 1, 217-226. 2-4 September, Northumbria, UK.

Suárez Sánchez, F.A., Carvajal-Peláez, G.I., \& Catala-Alis, J. (2017). Occupational safety and health in construction: a review of applications and trends. Industrial Health, 55(3), 210-218. https://doi.org/10.2486/indhealth.2016-0108

Suraji, A., Duff, A.R., \& Peckitt, S.J. (2001). Development of causal model of construction accident causation. Journal of Construction Engineering and Management. https://doi.org/10.1227/01.NEU.0000210260.55124.A4 
Szymberski, R. (1997). Construction Project Safety Planning. TAPPI Journal.

Tackett, J., Goodrum, P.M., \& Maloney, W.F. (2006). Safety and Health Training in Construction in Kentucky. June.

Takim, R., \& Akintoye, A. (2002). Performance indicators for successful construction project performance. In University of Nortbumbria. Association of Researchers in Construction Management.

Tam, C.M., Zeng, S.X., \& Deng, Z.M. (2004). Identifying elements of poor construction safety management in China. In Safety Science. https://doi.org/10.1016/j.ssci.2003.09.001

Tappura, S., Nenonen, N., \& Kivistö-Rahnasto, J. (2017). Managers' viewpoint on factors influencing their commitment to safety: An empirical investigation in five Finnish industrial organisations. Safety Science, 96, 52-61. https://doi.org/10.1016/j.ssci.2017.03.007

Teo, E.A.L., Ling, F.Y.Y., \& Ong, D.S.Y. (2005). Fostering safe work behaviour in workers at construction sites. Engineering, Construction and Architectural Management. https://doi.org/10.1108/09699980510608848

Teo, E., \& Lin, A.I. (2005). Singapore's contarctors' attitudes towards safety culture. Journal of Construction Research. https://doi.org/10.1142/S1609945105000316

Toole, T.M., \& Gambatese, J. (2008). The Trajectories of Prevention through Design in Construction. 39, 225-230. https://doi.org/10.1016/j.jsr.2008.02.026

Tymvios, N., \& Gambatese, J.A. (2016). Perceptions about Design for Construction Worker Safety: Viewpoints from Contractors, Designers, and University Facility Owners. Journal of Construction Engineering and Management. https://doi.org/10.1061/(ASCE)CO.1943-7862.0001067

Ulang, N. (2005). Communication of Construction Health and Safety Information in Design. In Dainty, A.R.J. (Ed.), Proceedings 25th Annual ARCOM Conference, Association of Researchers in Construction Management, 2, 1233-1241. 7-9 September 2009, Nottingham, UK.

Umeokafor, N. (2017). An appraisal of the barriers to client involvement in health and safety in Nigeria's construction industry. Journal of Engineering, Design and Technology. https://doi.org/10.1108/JEDT-06-2016-0034

Umeokafor, N., Kostis, E., Lundy, S., Isaac, D., Stuart, A., Igwegbe, U. et al. (2014). The Pattern of Occupational Accidents, Injuries, Accident Causal Factors and Intervention in Nigerian Factories. Developing Country Studies.

Umoh, G.I., \& Torbira, L.L. (2013). Safety Practices and the Productivity of Employees in. International Journal of Business and Management Review, 1(3), 128-137.

van der Molen, H.F., Basnet, P., Hoonakker, P.L.T., Lehtola, M.M., Lappalainen, J., Frings-Dresen, M.H.W. et al. (2018). Interventions to prevent injuries in construction workers. In Cochrane Database of Systematic Reviews. https://doi.org/10.1002/14651858.CD006251.pub4

Vinodkumar, M.N., \& Bhasi, M. (2010). Safety management practices and safety behaviour: Assessing the mediating role of safety knowledge and motivation. Accident Analysis and Prevention, 42(6), 2082-2093.

https://doi.org/10.1016/j.aap.2010.06.021

Vitharana, V.H.P., De Silva, G.H.M.J.S., \& De Silva, S. (2015). Health Hazards, Risk and Safety Practices in Construction Sites - A Review Study. The Institution of Engineers, Sri Lanka, XLVIII(03), 35-44. https://doi.org/10.4038/engineer.v48i3.6840

Wachter, J.K., \& Yorio, P.L. (2014). A system of safety management practices and worker engagement for reducing and preventing accidents: An empirical and theoretical investigation. Accident Analysis and Prevention, 68. https://doi.org/10.1016/j.aap.2013.07.029

Weidman, J., Dickerson, D.E., \& Koebel, C.T. (2015). Prevention through Design Adoption Readiness Model (PtD ARM): An integrated conceptual model. Work. https://doi.org/10.3233/WOR-152109

Weinstein, M., Gambatese, J., Asce, M., \& Hecker, S. (2005). Can Design Improve Construction Safety ?: Assessing the Impact of a Collaborative Safety-in-Design Process, 131(October), 1125-1134. https://doi.org/10.1061/(ASCE)07339364(2005)131:10(1125) 
Williams, J.H. (2008). Improving participation in safety. Professional Safety, 53(12), 40-45.

Williams, O.S., Adul-Hamid, R., \& Misnan, M.S. (2018). Accident Causal Factors on the Building Construction Sites: A Review. International Journal of Built Environment and Sustainability, 5(1), 78-92. https://doi.org/10.11113/ijbes.v5.n1.248

Wu, C., Li, N., \& Fang, D. (2017). Leadership improvement and its impact on workplace safety in construction projects: A conceptual model and action research. International Journal of Project Management. https://doi.org/10.1016/j.ijproman.2017.08.013

Wu, C., Wang, F., Zou, P.X.W., \& Fang, D. (2016). How safety leadership works among owners, contractors and subcontractors in construction projects. International Journal of Project Management. https://doi.org/10.1016/j.ijproman.2016.02.013

Wu, W., Gibb, A.G.F., \& Li, Q. (2010). Accident precursors and near misses on construction sites: An investigative tool to derive information from accident databases. Safety Science. https://doi.org/10.1016/j.ssci.2010.04.009

Xinyu, H., \& Hinze, J. (2006). Owner, Äôs Role in Construction Safety: Guidance Model. Journal of Construction Engineering \& Management. https://doi.org/10.1061/(ASCE)0733-9364(2006)132:2(174)

Zahoor, H., Chan, A., Utama, W., Gao, R., \& Zafar, I. (2017). Modeling the Relationship between Safety Climate and Safety Performance in a Developing Construction Industry: A Cross-Cultural Validation Study. International Journal of Environmental Research and Public Health, 14(4), 351. https://doi.org/10.3390/ijerph14040351

Zhang, R., Zhou, Y., Zhuang, H., \& Zhu, X. (2015). Study on the project supervision system based on the principal-agent theory. Journal of Industrial Engineering and Management. https://doi.org/10.3926/jiem.1328

Zhou, W., Whyte, J., \& Sacks, R. (2012). Construction safety and digital design: A review. Automation in Construction, 22, 102-111. https://doi.org/10.1016/j.autcon.2011.07.005

Zwetsloot, G.I.J.M., Kines, P., Ruotsala, R., Drupsteen, L., Merivirta, M.L., \& Bezemer, R.A. (2017). The importance of commitment, communication, culture and learning for the implementation of the Zero Accident Vision in 27 companies in Europe. Safety Science, 96, 22-32. https://doi.org/10.1016/j.ssci.2017.03.001

Journal of Industrial Engineering and Management, 2020 (www.jiem.org)

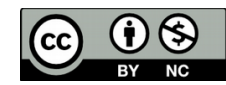

Article's contents are provided on an Attribution-Non Commercial 4.0 Creative commons International License. Readers are allowed to copy, distribute and communicate article's contents, provided the author's and Journal of Industrial Engineering and Management's names are included. It must not be used for commercial purposes. To see the complete license contents, please visit https://creativecommons.org/licenses/by-nc/4.0/. 